UDK 262.2(497.5 Žminj)"17"

314(497.5 Žminj)"17

Predano: 9. 1. 2017.

Prihvaćeno: 1. 6. 2017.

Izvorni znanstveni rad

DOI: $10.22586 /$ pp.v52i0.6

\title{
Vjersko i društveno ozračje Žminjštine u prvoj polovici 18. stoljeća
}

\author{
Elvis Orbanić \\ Državni arhiv u Pazinu \\ Vladimira Nazora 3 \\ 52000 Pazin \\ Republika Hrvatska \\ E-adresa: elvis.orbanic@dapa.hr
}

Župa Žminj bila je dijelom Porečke biskupije, a u državnome smislu potpadala je pod Habsburško Carstvo tijekom 18. stoljeća. U članku je predstavljen vjerski i društveni život ove rimokatoličke župe osobito pred kraj prve polovine spomenutoga stoljeća. U prvome redu predstavljene su onodobne crkvene strukture na razini zbornoga kaptola i župe. Donose se kratki biografski podatci o tada djelatnim svećenicima, ukazuje se na etnički sastav župe posredstvom prezimena klerika i laika u vidu gastalda i upravitelja oltara i crkava te se opisuju hodočašća, procesije i ostale pobožnosti koje su karakterizirale ovo mjesto u spomenutome vremenu. Članak se temelji - osim na literaturi - ujedno i na neobjavljenim vrelima, poglavito vizitacijskim zapisnicima i matičnim knjigama župe Žminj.

Ključne riječi: Žminj, Porečka biskupija, vjerski život, demografija, vizitacije.

\section{Uvod}

Žminj je u prvoj polovici 18. stoljeća bio sastavnicom upravne cjeline poznate kao Pazinska knežija, a ova u znaku plemićke obitelji Turinetti de Prie’, koja je bila njezin vlasnik od 1708. do 1766. godine kada će vlasništvo prijeći na grofovsku obitelj Montecuccoli. ${ }^{1}$ Knežija je pak bila dijelom austrijskih nasljednih

\footnotetext{
1 Markizima de Prie' prethodili su knezovi Auersperg kao vlasnici Knežije od 1665. godine. Pazinsku knežiju 1701. godine otkupit će od Auerspergovih Unutarnjoaustrijska dvorska komora, a od nje marki-
} 
zemalja, a ove sastavnicom Svetoga Rimskog Carstva na čijemu je čelu bila obitelj Habsburg.

U upravnome smislu Žminj toga vremena bio je općinska zajednica na čelu sa županom kao predstavnikom stanovništva prema vlastima Knežije, to jest prema njezinome kapetanu zaduženome u ime vlasnika voditi ju u vojnom, sudbenom, fiskalnom i upravnom smislu. ${ }^{2}$

Aresovi pokliči iz prve polovice 17. stoljeća ${ }^{3}$ na Žminjštini su u naslovu omeđenoga doba bili davna prošlost, što je zacijelo omogućilo okolnosti naklonjene privrednome rastu posljedično čega i materijalnoj izgradnji i obnovi crkvenih zdanja u duhu tada suverenoga baroka. ${ }^{4}$

Vjerska prošlost ovoga mjesta dubokom je brazdom povezana s onom Porečke biskupije, počevši od njegova prvog spomena 1178 . godine pa na dalje. ${ }^{5}$ Žminj je smatran jednim od važnijih središta kršćanstva navedene Biskupije s obzirom na to da je osim kao župa ujedno bio i sjedište takozvanoga zbornog kaptola. ${ }^{6}$ Svećenici koji su sačinjavali ovaj kaptol, kako ćemo detaljnije kasnije pokazati, bili su dužni zajedno vršiti koralnu službu u župnoj crkvi, što je činilo i bit kaptola kao crkvenoga instituta na ovoj razini. Porečki je ordinarij, držeći se propisa zadanih Tridentinskim koncilom, revno obilazio sve svoje župe, no to je - s onom žminjskom kao i ostalim župama, koje su politički pokrivene plaštem dinastije Habsburg, za razliku od onih pod skutima Serenissime - bilo poprilično otežano, a o čemu je dosadašnja historiografija ponešto napisala. ${ }^{7}$ Usprkos prorijeđenim vizitacijama župa u središnjoj Istri (a’ parte Austriaca) biskupi su obavljali svoju

zi de Prie'. Camillo De Franceschi, Storia documentata della Contea di Pisino (Venezia: editrice Societa' Istriana di Archeologia e Storia Patria, 1964), 116, 118.

2 "Pazinska knežija", u: Hrvatska enciklopedija, sv. 8 (Zagreb: Leksikografki zavod Miroslav Krleža, 2006), 345.

3 De Franceschi, Storia documentata, 91-96.

4 Stanoviti procvat potvrđuje i obnova obližnjega samostana u Svetom Petru u Šumi koncem 17. stoljeća, a nova crkva ondje je izgrađena početkom 18. stoljeća. Đurđica Cvitanović, "Srce Zagorja u srcu Istre”, u: Sv. Petar u Šumi nekad i danas, ur. Mario Bratulić, Ladislav Turčinović (Sv. Petar u Šumi: MZ Sv. Petar u Šumi, 1989), 36-37.)

5 Mate Križman, "Isprava pape Aleksandra III. iz 1178. godine. Paleografski i filološki pristup", u: Libri žminjski, sv. 2, ur. Slavko Krajcar (Žminj: Katedra Čakavskog sabora Žminj, 2008), 27-39.

6 Zborni kaptoli bili su smješteni u važnijim središtima biskupija, ali uvijek izvan biskupijskoga sjedišta gdje je postojao stolni kaptol. Uz njih su postojali još i ruralni ili seoski, ladanjski kaptoli, što su zajednica većega broja domaćih svećenika koji su obavljali zajedno korsku službu. U većim župama na obližnjemu Krku znalo je u seoskome kaptolu biti i do pedeset-šezdeset svećenika glagoljaša. Mihovil Bolonić, "Seoski kaptoli u Krčkoj biskupiji”, Bogoslovska smotra 36 (1966): 123. Žminj kao sjedište zborno-župne crkve navodi u relaciji ad limina bp. De Grassi 1730. godine. Ivan Grah, "Pazinski kraj u izvještajima pićanskih i porečkih biskupa Svetoj Stolici (1588-1780)", Vjesnik historijskih arhiva u Rijeci i Pazinu (dalje: VHARP) 26 (1983): 211.

7 Porečka biskupija u austrijskom dijelu Istre imala je sljedeće župe: Pazin, Stari Pazin, Beram, Sveti Petar u Šumi, Tinjan, Kašćergu, Grdoselo, Kringa, Trviž, Zamask i Žminj. De Franceschi, Storia documentata, 356-357; Grah, "Pazinski kraj", 201, 210-211; Grah, "Izvještaji porečkih biskupa Svetoj Stolici (1588-1775)", Croatica Christiana periodica 7 (1983), br. 12: 36, bilj. 97. 
zadaću i ostavili trag pregledanoga, svojevrsnu inventuru materijalnoga stanja crkava, crkvenih instituta i dobara kao i ljudskoga, duhovničkog potencijala. Zahvaljujući upravo spomenutim zapisima možemo graditi svoje spoznaje o nizu pitanja o duhovnom, ali i o kulturnom te društvenom ozračju koje je vladalo Žminjštinom u prvoj polovici 18. stoljeća, što se preklapa s vremenom izgradnje današnje župne crkve.

Naime, u prvoj polovici 18. stoljeća vizitacije župe Žminj obavljene su, prema dosadašnjim spoznajama, u dva navrata, to jest 1710 . i 1745 . godine, ${ }^{8}$ a u ovoj historiografskoj raščlambi sondirat ćemo zapisnik vizitacije žminjske župe, navlastito potonje godine, jer nam donosi cjelovitiji pogled na niz istraživačkih pitanja od onoga s početka stoljeća, što je sačuvan u još skromnijim fragmentima.

Biskupi, dakako, nisu sami dolazili u pastoralni pohod Žminju; imali su svitu za koju se može napisati da je bila barokne brojnosti i običaja, što je i priličilo pripadajućemu povijesnom razdoblju. Tako su u pratnji monsinjora Gaspara Negrija, ${ }^{9}$ porečkoga biskupa, prigodom vizitiranja austrijskoga dijela Biskupije 1745. godine u njegovoj asistenciji bili: don Valentino Valentini, katedralni kanonik i suvizitator s naslovom provikara penitencijara (col titoto di Pro Vicario di Penitenzione), dr. Antonio Vergotin, kanonik, biskupijski kancelar i suvizitator, koji je bio i zapisničar vizitacije, ${ }^{10}$ don Giovanni Cane' ekonom i biskupov tajnik; don Giovanni Battista de Rossi ceremonijar (majestro de cerimonie); don Paolo Chiuno, biskupijski potkancelar e pro Candatario; don Antonio Ravasini, župnik Novaka i vizitator seoskih prostora (visitator di Campagna), koji je ujedno bio zadužen za prtljagu putnika i kao prevoditelj za hrvatsku pastvu (direttore del Bagaglio e interprete per gli Illirici), ${ }^{11}$ don Felice Bossi, osobni biskupov sobar te dvojica sluga: Antonio Jermanin i Antonio Marzocco (sluga di livrea). ${ }^{12} \mathrm{Za}-$ cijelo su svi oni, to jest uz biskupa još osam pratitelja, bili u Žminju početkom srpnja spomenute godine. To je, razumljivo, za župu i kòmunu značilo određeno

8 Grah, "Izvještaji porečkih biskupa", 36. bilj. 97; Jakov Jelinčić, Elena Uljančić Vekić, "Popis lokaliteta pastoralnih vizitacija porečkih biskupa u 17. i 18. st., Vjesnik istarskog arhiva (dalje: VIA) 8-10 (2001 2003): 172.

9 Gaspar Negri postao je porečkim biskupom 22. siječnja 1742. godine, a umro je 18. siječnja 1778. godine. Francesco Babudri, "I vescovi di Parenzo e la loro cronologia", Atti e Memorie della Societa Istriana di Archeologia e Storia Patria (dalje: AMSI) 25 (1909): 272-273.

${ }_{10}$ Republika Hrvatska - Biskupijski arhiv u Poreču (dalje: BAP) - Biskupske vizitacije (dalje: BV), Knjiga 27(1745), 309.

${ }^{11}$ Kada je središnja Istra u pitanju, to jest njezin dio pod upravom porečkoga biskupa, pojam Illirici nedvojbeno upućuje na hrvatski puk. Vidi o etnonimima Iliri i Hrvati u: Ivo Rendić-Miočević, Hrvatski identitet: trajnost i fluidnost: usporedba Kvarnera i gorske Dalmacije (Rijeka: Adamić, 2006), 82-83. Heterogenost kulturnoga kruga i etnonima, osobito priobalnoga dijela Istre, odražava nazočnost (osim Talijana i Hrvata) ujedno i drugih etničkih skupina. Vidi npr.: Miroslav Bertoša, "Istra se zove različitost. Kolonizacijski etnički iceberg XVI-XVIII. stoljeća” Istra (1987), br. 5-6: 167-173.

${ }_{12}$ Li Seguenti Soggetti furono in Seguito di Mons. Ill.mo e Rev.mo Vescovo in Visita. BAP-BV, Knjiga 27 (1745), 68 . 
financijsko opterećenje jer riječ je o uglednim gostima koje je trebalo primjereno smjestiti i uzorno ugostiti. ${ }^{13}$

Dolazak u Žminj, nakon 35 godina izbivanja, bio je očekivano svečan za biskupa. Izgledao je ovako: dana 9. srpnja spomenute 1745. godine navečer oko 23 sata došao je u Beram žminjski župnik Miloš (Sebastiano Millos) zajedno s još jednim svećenikom čije nam ime izvor ne otkriva, a mogao je to biti bilo koji od desetorice klerika koji su tada službovali u kolegijalnoj žminjskoj crkvi (isključivši kanonika iz razloga subjektivne prirode, što ćemo u kasnijim recima razjasniti). Došli su u susret biskupu i njegovoj pratnji dovodeći kola s konjskom vučom. U 7 sati u jutro monsinjor biskup zajedno s pratnjom krenuo je prema Žminju, a kada je jednom došao na granicu žminjskoga kòmuna, dočekala ga je skupina od 24 vojnika koji su zapucali u znak dobrodošlice iz tadašnjega vatrenog oružja, takozvanih musketa. ${ }^{14}$ Prethodili su mu sve do ulaska u crkvu gdje je sišavši s konja bio pozdravljen ponovljenim pucanjem kako prilikom njegova ulaska, tako i izlaska iz crkve. Nakon toga je biskup s pratnjom odveden u kuću gdje će boraviti. ${ }^{15}$ Sljedećeg jutra monsinjor Negri imao je svečani ulazak u kolegijalnu crkvu praćen pazinskim kapetanom Martinom de Terzijem, ${ }^{16}$ koji je bio povjerenik Njezinoga Veličanstva kraljice Marije Terezije. Posebno pozdravljen od župnika, kanonika i ostaloga klera, otpjevavši pontifikalnu misu, krenuo je držati vjeronauk djeci. Nakon toga vratio se u kuću da bi se nakon ručka u popodnevnim satima vratio u crkvu i podijelio krizmu brojnome narodu. Krizmu je dijelio i sljedećega jutra nakon obavljene tihe mise kada je i pričestio mnoštvo. ${ }^{17}$ Valja pojasniti da se zbog biskupova rijetkog dolaženja u župe austrijske Istre sakrament krizme isto tako rijetko dijelio pa je tomu razlog i ovo mnoštva nekrizmanih.

A evo kako je izgledao oproštaj s austrijskom Istrom. Dana 23. srpnja nakon ručka krenuo je monsinjor Negri sa svitom na konju i uz pratnju presvijetloga pazinskog kapetana i prepozita ${ }^{18}$ na granicu s Venecijom. Sjahali su i ispozdravljali se s

\footnotetext{
${ }^{13}$ Usporedbe radi u župi Brdo, prigodom duhovne vizitacije koju je poduzeo u svibnju 1748. godine tamošnji ordinarij Cecotti župnik je za njega, generalnoga vikara, tri svećenika i dvojicu sluga za tri objeda potrošio petnaest lira uključujući i sijeno za konje (cavalcatura). Dakle, pićanski biskup bio je nešto skromniji - gledano kroz prizmu pratnje - u odnosu na svoga porečkog kolegu, što je i razumljivo uzmemo li u obzir samo površinu biskupije. Arhiv Republike Slovenije - Reprezentanca in komora za Kranjsko, fasc. 19, 20: Brdo.

${ }^{14}$ Musketa je ručno vatreno oružje ranoga novog vijeka. Javlja se početkom 16. stoljeća najprije u Španjolskoj pa se širi Europom. Bila je glavno pješadijsko oružje u 16. i 17. stoljeća. Sastojala se od cijevi, uređaja za opaljivanje, kundaka, podupirača za naslon i pribora. Sredinom 17. stoljeća dobila je bajunetu, čime je postala, po nekima, prava puška. Slobodan Radisavljević, "Musketa", u: Vojna enciklopedija, sv. 5 (Beograd: izdanje Redakcije Vojne enciklopedije, 1973), 660-661.

${ }_{15}$ BAP-BV, Generalna vizitacija biskupa Negrija u austrijskom dijelu biskupije, Negri Visitatio Generalis a Parte Austriaca, 2.27 (1745), 32.

${ }^{16}$ Martin de Terzi bit će kapetan Pazinske knežije od 1739. do 1757. De Franceschi, Storia documentata, 120.

17 BAP-BV, Knjiga 2.27 (1745), 33-34.

${ }^{18}$ BAP-BV, Knjiga 2.27 (1745), 67.
} 
ocem biskupom. Kapetan je, pretpostavljamo radi kurtoazije, izrazio žaljenje što biskup ne može ostati još bar jedan tjedan. Svita s biskupom nastavila je hodom prema Svetome Ivanu od Šterne i potom u jedan iza ponoći stigla u Poreč. ${ }^{19}$

\section{Stanovništvo Žminja 1745. godine}

Da bi u historiografski mogućim dosezima prikazali vjersko stanje ove kršćanske zajednice u prvoj polovici promatranoga stoljeća, osvrnut ćemo se na njezin društveni okvir koji predstavlja ponajprije brojnost župljana. U ovome predstatističkom vremenu župnici su bili dužni iznijeti biskupu podatak o broju pričešćenih i nepričešćenih župljana. Broj nepričešćenih u tome je korpusu označavao oko jedne trećine od ukupnoga broja kod župnika evidentiranih stanovnika. Valja napomenuti da se prva pričest tada primala s oko četrnaest godina. ${ }^{20}$ Iz 1710. godine datira prvi precizan podatak o broju duša u ovoj župi 18. stoljeća. Bilo ih je 1787 od pričesti. ${ }^{21}$ Trideset pet godina kasnije u žminjskoj je kršćanskoj zajednici živjelo 1605 duša od pričesti ili 2442 osoba sveukupno, ${ }^{22}$ što znači da su u odnosu na kompletno stanovništvo $34 \%$ sačinjavale osobe do 14 . godine starosti. U zapisnicima obje vizitacije nema navedenih osoba kojima je zabranjena pričest, a koje bi, da postoje, trebalo uračunati u ove brojčane odnose.

Tablica 1. Broj stanovnika po župama 1745. godine ${ }^{23}$

\begin{tabular}{|c|c|c|c|c|c|c|c|c|c|c|}
\hline Pazin & $\begin{array}{c}\text { Stari } \\
\text { Pazin }\end{array}$ & $\begin{array}{c}\text { Grdo- } \\
\text { selo }\end{array}$ & $\begin{array}{c}\text { Kašćer- } \\
\text { ga }\end{array}$ & Trviž & Beram & Žminj & $\begin{array}{c}\text { Sveti } \\
\text { Petar u } \\
\text { Šumi }\end{array}$ & Kringa & Tinjan & ukupno \\
\hline 1424 & 444 & 400 & 340 & 524 & 460 & 2442 & 450 & 500 & 972 & 7956 \\
\hline
\end{tabular}

Iz navedenih podataka (Usp. Tablica 1) najmnogoljudnija župa Porečke biskupije $\mathrm{u}$ austrijskome dijelu Istre jest Žminj, potom slijedi Pazin gdje je sjedište prepozita i vanjskoga vikara Porečkoga biskupa, a na trećemu je mjestu po brojnosti Tinjan. Historiografija još nije objasnila razloge ovakvih razlika u brojnosti žitelja kada uspoređujemo administrativno središte Knežije - Pazin i pograničan kaštel kakav je bio u to vrijeme Žminj. No, ako se na kronološkoj ljestvici spustimo niže,

\footnotetext{
${ }^{19}$ (...) spiegandogli esso Sig. Capitano lo spiacere di cosi sua presta partenza dallo Stato Austriaco ne fece il possibile che si fermasse per una settimana ancora. Cio' fatto si e’ preso il Camino per sitto San Gioanni di Sterna e alla una della notte siamo pervenuti a Parenzo. BAP-BV, Knjiga 2.27 (1745), 68.

${ }^{20}$ Jakov Jelinčić, "Vizitacija porečkog biskupa Gaspara Negrija iz 1743. - 1748.", u: 2. Istarski povijesni biennale, ur. Neven Budak (Poreč: Zavičajni muzej Poreštine, Sveučilište Jurja Dobrile u Puli, Državni arhiv u Pazinu, 2007), 196.

${ }^{21}$ BAP-BV, Knjiga osme vizitacije Aleksandra Adelsija, Adelasio Octavae visitationis generalis 1710, 2.17(1710), 102.

22 BAP-BV, Knjiga 2.27 (1745), 304.

${ }^{23}$ BAP-BV, Knjiga 2.27 (1745), 79; Jelinčić, "Vizitacija porečkog biskupa Gaspara Negrija”, 197.
} 
zamijetit ćemo da je i u 17. stoljeću (poimence 1677. godine) sličan omjer stanovnika. ${ }^{24} \mathrm{U}$ zaključivanju nećemo brzati jer su podaci, poglavito za 17. stoljeće, samo okvirni. Ipak, usuđujemo se donekle ukazati na smanjenje razlika iako i sredinom 18. stoljeća Žminj - prateći brojčane odnose - dobrano prednjači pred Pazinom kao i ostalim župama austrijske Istre. Ta će brojnost, a s njome vjerojatno povezana i ekonomska mogućnost, utjecati na izgradnju i barokizaciju žminjske sakralne baštine. Zato ne treba čuditi što je upravo Žminj, a ne Pazin koji mu je bio duhovno pretpostavljen po činjenici sjedišta biskupova namjesnika (vanjskoga vikara), vremenski prednjačio u aktivnostima sakralno-materijalne izgradnje. ${ }^{25}$

U župi je, ako za ovu priliku promotrimo samo 1745. godinu, kršteno sedamdeset osoba, ${ }^{26}$ a te iste godine u Žminju su umrle i pokopane 53 osobe. Što se dosizanja životne dobi tiče, zamijetit ćemo da je najstariji župljanin Petar Bianchi doživio 98 godina. ${ }^{27}$ Ta visoka starost ne bi nas smjela zavarati jer je prosječna životna dob za one koji su nadživjeli prvu godinu života tada u Žminju iznosila 33 godine. Naime, smrtnost osoba (do 18. rođendana) u Žminju je toga istog nadnevka (1745.) iznosila čak $53 \% .{ }^{28}$ Ukapanja župljana vršila su se u župnoj crkvi gdje su u prvome redu pokapani svećenici, zatim u onoj Sv. Križa, na groblju potonje crkve i u crkvi Sv. Trojstva. Djeca su se mahom pokapala pod lođom Sv. Križa (sub lodia Sanctae Crucis in tumba angelorum) ${ }^{29}$

\section{Broj i struktura klerika}

Župa Žminj početak 18. stoljeća dočekuje pod vodstvom Santeta Rovisa, kojega je na službu župnika izabrao gospodar Pazinske knežije princ Auersperg, što je potvrdio ondašnji porečki biskup, ${ }^{30}$ kako je i prije i poslije Rovisa bila uobičajena praksa. ${ }^{31}$ Iako nemamo sačuvan detaljan podatak o njegovome

\footnotetext{
${ }^{24}$ U Žminju je bilo oko dvije tisuće duša, a u Pazinu oko tisuću duša. Elvis Orbanić, "Društveni i religiozni život Porečke biskupije „a parte Imperij“ u 17. st.: primjer Pazina, Starog Pazina, Svetog Petra u Šumi i Žminja" (doktorska disertacija, Sveučilište u Zagrebu, 2012), 239-249.

${ }^{25}$ Vidi: Vladimir Marković, Crkve 17. i 8. st. u Istri: tipologija i stil (Zagreb: Institut za povijest umjetnosti, 2004), 24-26.

${ }^{26}$ Župni ured Žminj (dalje: ŽUŽ) - Matična knjiga krštenih Žminj (1716-1746), 131-136.

${ }^{27}$ Republika Hrvatska (dalje: HR) - Državni arhiv u Pazinu (dalje: DAPA) - Zbirka matičnih knjiga 429, HR-DAPA-429, Zbirka matičnih knjiga, MKU Žminj (1716-1774), 22. prosinca 1745. U ovome zapisu stoji da je riječ o okvirnim godinama pokojnika (annorum 98 circiter) kao što je uobičajeno za tadašnje upise. Nismo u mogućnosti otkriti odgovara li navedeni podatak o navršenim godinama stvarnosti jer župa Žminj ima sačuvanu Matičnu knjigu krštenih tek od 1662. godine.

${ }^{28}$ Visoka smrtnost djece opažena je i u Poreču promatranih godina. O tome vidi: Egidio Ivetic, "La popolazione di Parenzo del Settecento: aspetti, prolemi ed episodi del movimento demografico", Atti CRSR 21 (1991): 147-148.

${ }^{29}$ HR-DAPA-429, Zbirka matičnih knjiga, MKU Žminj (1716-1774), sub a. 1745.

${ }^{30}$ BAP-BV, Knjiga 17 (1710), 100.

${ }^{31}$ I markiz a Prie', kao vlasnik Knežije, uživao je patronatsko pravo nad pazinskom prepoziturom, zbornom crkvom u Žminju i nad župnim crkvama Knežije. Grah, "Pazinski kraj”, 211. O crkvenim službama
} 
preuzimanju službe župnika, prema upisima u matičnu knjigu krštenih po prvi puta zatječemo ga kao krstitelja Ivana, sina Mihaela Rafaela i supruge mu Jakove koncem svibnja 1699. godine, ${ }^{32}$ što je nadnevak post quem non za njegov dolazak na čelo ove župe. Dakle, pastirski rad Santeta Rovisa na Žminjštini možemo pratiti od proljeća 1699. godine pa sve do 3. rujna 1729. godine kada je umro u 57. godini života. ${ }^{33}$ U Matičnoj knjizi umrlih, u koju je vjerojatno i sam upisivao preminule župljane, jednom se prilikom zapisao (osim na latinskome) ujedno i u grčkoj kombinaciji slova, svojevrsnome kriptogramu, čime je (predmnijevamo) želio dati do znanja vlastitu verziranost u više jezika i pisama koje je mogao savladati u porečkome sjemeništu. ${ }^{34} \mathrm{U}$ trajnijoj memoriji Žminjštine ostat će upamćen jer su za vrijeme njegova župnikovanja podignuti i obnovljeni svi oltari župne crkve (Vidi Tablica 2) kao i krstionica 1710. godine. ${ }^{35}$

Tablica 2. Godine izgradnje mramornih oltara župne crkve u Žminju ${ }^{36}$

\begin{tabular}{|c|c|}
\hline Godina & Naziv oltara \\
\hline 1704. & Presveti Ružarij \\
\hline 1706. & Glavni oltar \\
\hline 1707. & Općinstvo Svetih \\
\hline 1708. & Bogorodica \\
\hline 1708. & Sv. Križ \\
\hline 1714. & Prikazanje u Hramu \\
\hline 1724. & Sv. Barbara \\
\hline
\end{tabular}

i nadarbinama u srednjem vijeku na prostoru Hrvatske vidi: Jadranka Neralić, Put do crkvene nadarbine, (Split: Književni krug, 2007).

${ }^{32}$ Joannes filius legitimus Michaelis Rafael et Jacoma eius uxoris a me Canonico ac Plebano Sancto Rouis sacrum baptisma suscepit; q. Petrus Matohich ac Perina filia defuncti Domini Supani Leonardi Rouis ad sacrum tenere fontem. ŽUŽ-Matična knjiga krštenih Žminj (1662-1713), 29. 5. 1699.

${ }_{33}$ ŽUŽ-Matična knjiga umrlih (1784-1812), popis umrlih svećenika u župi; HR-DAPA-429, MKU Žminj (1716-1774), 3. 9. 1729.

${ }^{34}$ Bp. Adelasio otvorio je sjemenište u Poreču koje je djelovalo i u razdoblju od 1680. do 1689. godine, a koje je mogao pohađati i budući žminjski župnik Sante Rovis. Iza te godine jedan je svećenik besplatno poučavao mladiće. Ivan Grah, "Sjemeništa i teološko obrazovanje na području istarskih biskupija”, u: Visoko školstvo na području Riječko-senjske metropolije, ur. Mile Bogović (Zagreb; Rijeka: Kršćanska sadašnjost; Teologija u Rijeci, 1999), 231; Mario Pavat, La riforma tridentina del clero a Parenzo e Pola (Roma: ex Pontifica Universitate Gregoriana, 1960), 193. Zahvaljujem prof. dr. sc. Mati Križmanu na ljubaznim uputama.

35 Ante Šonje, Žminj i Žminjština (Žminj: Katedra čakavskog sabora Žminj, 1976), 104.

36 Šonje, Žminj i Žminjština, 102-104. 
Istaknuo se i u radovima na crkvi Sv. Foške gdje je podignuo pravokutno svetište baš u godini svoje smrti. ${ }^{37}$ Ipak, možda najdojmljiviji znamen koji je ostavio iza sebe posvjedočuje natpis na pročelju župne crkve izgrađene 1717. godine upravo njegovom brigom. ${ }^{38}$

Rovisa će naslijediti Jeronim De Zorzi (Girolamo de Zorzi), koji je djelovao kao župnik i 1731. godine kada je dopustio vođenje bratovštinske knjige Presvetoga sakramenta. ${ }^{39}$ Preminut će te iste godine 3 . svibnja u 57. godini života, a pokopan je u župnoj crkvi. ${ }^{40}$ De Zorzijev duhovni položaj - službu žminjskoga župnika preuzima Juraj Florianis (Giorgio Florianis), koji će ovdje biti djelatan svega nekoliko godina jer umire 11. listopada 1736. s navršenih 56 godina života. ${ }^{41} \mathrm{U}$ vrijeme Florianisovoga župnikovanja valja istaknuti 1734. godinu kada je u znak pobožnosti Ivan Krstitelj Rovis podigao kapelicu, što je najstarija sačuvana krajputašica ove župe. ${ }^{42}$

Vjerojatno zbog Florianisove bolesti već 28. listopada 1735. na njegovo mjesto ključnoga žminjskoga duhovnika dolazi Sebastijan Miloš (Sebastiano Millos), rođen u Pazinu 1686. godine ${ }^{43}$ - središnja figura duhovnosti Žminjštine u sljedećih devetnaest godina. Ovaj je u mladim danima opisan kao onaj koji je iskazujući veleban duh i jaku hrabrost (...) dimostrando un Spirito grandioso, e peto forte (...) ostavio zanat koji je obavljao u Pazinu te se potaknut Providnošću uputio na školovanje kako bi došao do izražaja njegov talent. No, spomenute Miloševe intelektualne namjere zapriječilo je osobno siromaštvo kojemu je pak doskočila Margarita Balde, duhovno plemenita služavka u presvijetle plemenitaške pazinske obitelji Rampelli ${ }^{44}$ posudivši mu tako potrebne 52 lire i 10 solda za školovanje. ${ }^{45}$ Miloš je u vrijeme imenovanja župnikom u Žminju bio kanonik i župnik u Svetome Lovreču ${ }^{46}$ (Mletačka Istra) gdje je djelovao pune 23 godine i 8 mjeseci. ${ }^{47}$ Početkom četrdesetih godina 18 . stoljeća bio je na položaju čak i vanjskoga vikara

\footnotetext{
37 Šonje, Žminj i Žminjština, 110.

38 Šonje navodi kao godinu izgradnje pročelja župne crkve 1718. godinu. Šonje, Žminj i Žminjština, 101, a Marković 1717. Marković, Crkve 17. i 18. st. u Istri, 26.

39 ŽUŽ, Libro della Scola del Santissmo Sacramento, naslovnica.

40 ŽUŽ-MKU (1784-1812), popis umrlih svećenika u župi; HR-DAPA-429, Zbirka matičnih knjiga, MKU Žminj (1716-1774), 3. 5. 1731., 33: Hieronimus De Zorzi.

${ }^{41}$ ŽUŽ-MKU (1784-1812), popis umrlih župnika; HR-DAPA-429, Zbirka matičnih knjiga, MKU Žminj (1716-1774), 39.

${ }^{42}$ Elvis Orbanić, Nela Peteh, “Žminjske kapelice: povijest jedne pučke pobožne prakse”, Riječki teološki časopis 24 (2016), br. 1: 72.

${ }^{43}$ BAP-BV, Knjiga 27 (1745), 303; precizan datum krštenja je 4. travnja 1686. (HR-DAPA-429, Zbirka matičnih knjiga, MKK, Pazin (1655 -1689), 159.

${ }^{44}$ O obitelji Rampel vidi: De Franceschi, Storia documentata, 222; Slaven Bertoša, "Rampel (Rampelli)", u: Istarska enciklopedija (Zagreb: Leksikografski zavod Miroslav Krleža, 2005), 673.

${ }^{45}$ Pismo koje je Anna Balde di Gallignana uputila biskupu. BAP-BV, Knjiga 27 (1745), 648.

${ }^{46}$ I Sv. Lovreč bio je sjedište zbornoga kaptola kao i Žminj. Pavat, La riforma tridentina, 209.

47 BAP-BV, Knjiga 27 (1745), 303.
} 
porečkoga biskupa ${ }^{48}$ čemu se svjetovna vlast usprotivila pišući nunciju u Beč i tražeći od monsinjora Negrija, po njegovu dolasku u Poreč, da ga odmah smijeni. Bio je na udaru svjetovnih vlasti i zato što je javno objavio u Žminju pastoralno pismo porečkoga biskupa, a da za to prethodno nije dobio i dozvolu države. ${ }^{49}$ Miloševi neprijatelji čak su ga prijavili da nije bio austrijski državljanin, na što se ovaj morao braniti i dokazivati suprotno. ${ }^{50}$ Njegovo župnikovanje Žminjem bit će pod teretom i inače popriličnih turbulencija po ovu malenu sredinu. Usprkos tome, župnik Miloš ostavit će iza sebe trag na dvama povećim graditeljskim pothvatima. Jedan je nastavak gradnje fasade župne kolegijalne crkve, ${ }^{51}$ a tu je i zvonik najstarije žminjske crkve posvećene sv. Foški, što je izgrađen upravo Miloševom brigom 1742. ili 1743. godine. ${ }^{52}$ Promatrajući ga u okviru svakodnevnih životnih briga, S. Miloš je poput prijašnjih župnika uzeo u najam jedan vrt Karmelske bratovštine, također je unajmio i jednu zgradu u vlasništvu Bratovštine sv. Mihovila, koja mu je služila kao staja za konje. Župnik je uz svećeničku službu unutar župne crkve imao obvezu misiti i u Sv. Bartolu i Sv. Agnezi godišnje po 21 misu za što je dobivao u novcima po 36 lira za svaku od navedene dvije crkve. ${ }^{53}$ Miloš će u službi žminjskoga župnika i kanonika ostati sve do svoje smrti 14. travnja 1754. godine. ${ }^{54}$ Pokopan je u župnoj crkvi idućega dana. ${ }^{55}$

Uz župnika Miloša u Žminju je službovao i kanonik Ivan Krstitelj Rovis (Giovanni Battista Rovis) ${ }^{56}$ jer je žminjska župa, kako smo u uvodu napomenuli, bila ujedno i sjedište kolegijalnoga (zbornog) kaptola. Na prostoru Pazinske knežije i to njezinom dijelu koji je potpadao pod upravu Porečkoga biskupa još su Tinjan i Pazin bili sjedišta kaptola spomenutoga tipa. ${ }^{57}$ Ivan K. Rovis rođen je 1712. godine, što znači da će prilikom vizitacije 1745. godine imati 33 godine. Sa šesnaest

\footnotetext{
${ }^{48}$ Dokaz tomu je i pismo čestitke koje Miloš kao vanjski vikar šalje 1. veljače 1742. monsinjoru Negriju povodom njegovoga prelaska s biskupske katedre Novigrada na onu Poreča. Babudri, "I vescovi di Parenzo", 272. Također je tu i epigrafska potvrda na zvoniku sv. Foške na kojemu zadnja godina nije posve čitljiva: ERRE(ctvm) / VIGILANTIA - R(everendissi)MI - D(omi)NI - SEBASTIANI / MILOS - CAN(onici) - ET- PLEB(ani) - VICARII / FOR(anei) - GASTALDI / ANTONII - MOTICA / PROTIVS MATTHIA — DVOICICH — ANNO / D(omi)NI MDCCLII. Šonje, Žminj i Žminjština, 111.

${ }_{49}$ (...) umilmente informo, che il sudetto Mons. Sig. Vescovo di Parenzo Gasparo de Negri informato della ignoranza, incapacita', et inquietudine del Don Millos sia subito nei primi giorni del suo Ingresso divenuto alla ammozione del detto Don Millos dal Vicariato Foraneo. BAP-BV, Knjiga 27 (1745), 178.

${ }^{50}$ Danijela Juričić-Čargo, "Arhivska građa za povijest Pazina i Pazinske grofovije u upravnim fondovima Arhiva Republike Slovenije”, VIA 2-3 (1992 - 1993): 228.

${ }^{51}$ Šonje, Žminj i Žminjština, 101. Fasada je izgrađena 1717. godine, dok će Miloš postati žminjski župnik tek 1735. godine, što nas upućuje na zaključak da je rad na fasadi potrajao i nakon 1717. godine.

52 Šonje, Žminj i Žminjština, 111.

${ }^{53}$ BAP-BV, Knjiga 27(1745), 622-623.

${ }^{54}$ ŽUŽ-MKU Žminj (1784-1812), popis umrlih župnika.

${ }^{55}$ HR-DAPA-429, Zbirka matičnih knjiga, MKU Žminj (1716-1774), 97.

${ }^{56}$ Iduće biografske crtice žminjskih svećenika temeljimo uglavnom na zapisniku pastoralne vizitacije iz 1745. godine.

${ }^{57}$ Pavat, La riforma tridentina, 210.
} 
godina obukao je kleričko odijelo, a s njim, iako se u vrelu ne spominje izrijekom, napravljena mu je i tonzura, što su bili onovremeni znaci pripadnosti crkvenome staležu. ${ }^{58}$ Niže kleričke redove, ${ }^{59}$ to jest ostijarijat, lektorat, egzorcistat i akolitat podijelio mu je monsinjor Pietro Grassi. ${ }^{60}$ Vlasnik Pazinske knežije markiz de Prie’ izabrao ga je na mjesto kanonika žminjskoga kolegijalnog kaptola 1728. godine, što će kazati da je kanonikom postao sa šesnaest godina. Monsinjor Vincenzo Mazzoleni, ${ }^{61}$ porečki biskup, podijelio mu je više svete redove (subđakonat, đakonat i prezbiterat) te već sedamnaest godina uživa spomenuti beneficij. Kanonik Ivan K. Rovis služi u kolegijalnoj crkvi i to na način da svakodnevno sudjeluje u koru, pjeva misu svim blagdanima kada dođe red na njega, nakon župnika i kapelana kurata. ${ }^{62}$ Ujedno mu je godišnja obveza služiti dvanaest misa u crkvi Sv. Marije Svetomore kao i u crkvi Sv. Križa ${ }^{63}$ Između župnika i kanonika postojale su određene trzavice, što ih iščitavamo kroz Miloševo prokazivanje Rovisa biskupu da ovaj ne ide po mjestu kao ostali klerici u kleričkome odijelu nego se oblači u odijelo boje kore drveta jednobojnih orukvica i napudrane kose. ${ }^{64}$

Sa župnikom i kanonikom u Žminju djeluje i svećenik Marin Žufić (Marino Suffich), koji je bio rođen 1675. godine pa je tijekom Negrijeve vizitacije imao sedamdeset godina. Zaredio ga je biskup Alessandro Adelasio ${ }^{65}$ te služi kao svećenik već 43 godine. Odmah po primanju svetih redova djelovao je u Svetome Mateju u Ceru tri godine da bi potom otišao u Stari Pazin za kapelana kurata gdje je ostao sljedećih šest godina. U Žminj se vratio u mansionariju pokojnoga župnika Antuna Žufića (Mansionario del q. Antonio Soffich Pievano). Godine 1714. nakon smrti svećenika Grgura Slivara (Gregorio Sliuar) Žminjski kaptol izabrao ga je za stalnoga kapelana (Capellania Perpetua) s dužnošću služenja dušama. Na taj položaj potvrdio ga je biskup Vaira. ${ }^{66}$ Žufić je nesmetano djelovao kao stalni kapelan u ovoj župi sve do 1738. godine kada je župnik Miloš izabrao novoga kapelana

\footnotetext{
${ }^{58}$ Jean Gaudemet, Storia del diritto canonico (Milano: Edizioni San Paolo, 1998), 721.

${ }^{59}$ O nižim i višim kleričkim redovima i praksu njihova podjeljivanja na primjeru susjedne Pićanske biskupije vidjeti u: Jakov Jelinčić, Knjiga ređenja u Pićnu (Prothocollum) 1632.-1783. (Pazin: Državni arhiv u Pazinu, Pazin 2015), passim.

${ }^{60}$ Pietro Grassi bio je porečki biskup od 14. ožujka 1711. do 16. ožujka 1731. godine. Babudri, "I vescovi di Parenzo", 271.)

${ }^{61}$ Vincenzo Maria Mazzoleni bio je porečki biskup od 18. lipnja 1731. do 16. prosinca 1741. godine. Babudri, "I vescovi di Parenzo", 271-272. Kao porečki biskup zadržao je i titulu krfskoga nadbiskupa. Pavat, La riforma tridentina, 91.

${ }^{62}$ BAP-BV, Knjiga 27 (1745), 310.

${ }^{63}$ BAP-BV, Knjiga 27 (1745), 623.

${ }^{64}$ (...) del Canonico Rovis che porta abito di scorso di albero di colore con manegotti da Vucolare o con polvere di Cipro sopra li capelli (...). BAP-BV, Knjiga 27 (1745): 306) Zahvalan dr. sc. Eleni Uljančić Vekić na pruženoj sugestiji oko prijevoda.

${ }^{65}$ Alessandro Adelasio bio je porečki biskup od 1. srpnja 1671. do kolovoza 1711. godine. Babudri, "I vescovi di Parenzo", 270.

${ }^{66}$ BAP-BV, Knjiga (1745): 314; Antonio Vaira bio je porečki biskup od 2. ožujka 1712. do 12. srpnja 1717. godine. Babudri, "I vescovi di Parenzo", 271.
} 
bez obzira na Kaptol i njega samoga. Dužnost mu je bila poput one župnika i kanonika sudjelovati svakodnevno u koru - gdje mu je pripadalo treće mjesto, nakon navedene dvojice - te služiti dušama kao župnikov pomoćnik. Prigodom vizitacije iz 1745. godine nije imao nikakav beneficij, ali sudjeluje u svečanim slavljima u crkvi. ${ }^{67}$ Rezultat vizitacije bio je i taj da je don Marin Žufić bio vraćen na mjesto kapelana kurata (stalnoga kapelana) i pripala mu je odnosna plaća, dok je župniku poručeno kako može slobodno izabrati sebi kapelana uz biskupovu potvrdu.$^{68}$ Kao kapelan služio je 46 godina u ovoj kolegijalnoj crkvi. Preminuo je 1. veljače 1763. godine te je pokopan u župnoj crkvi s navršenih 88 godina. ${ }^{69}$

Dakle, spomenute 1745. godine u župi su djelovala tri beneficijata (nadarbenika): župnik, kanonik i kapelan kurat te su sva trojica obvezna sudjelovati u koru. ${ }^{70}$ Kurata je trebao birati kaptol, a potvrđivao ga je porečki biskup, što je kao pravilo potvrđeno i nizom ranijih vizitacija. ${ }^{71}$

Župa je tada imala i sakristana, kojega je također birao kaptol, plaćao ga je jednim dijelom kaptol, a drugim dijelom kòmun (Communita). ${ }^{72}$

$\mathrm{U}$ isto vrijeme u Žminju zatječemo i don Franju Ksavera Rovisa (Francisco Xaverio Rovis), rođenoga 1701 . godine, koji je 1725. zaređen za svećenika. Od tada Rovis trajno služi ovoj žminjskoj Crkvi kao svećenik, a kao ispovjednik zadnjih osam godina od kada je dobio dozvolu ispovijedati. ${ }^{73}$ Biskup je njemu, kao i drugim žminjskim svećenicima, dao dopuštenje ispovijedati prilikom ove vizitacije. ${ }^{74}$ Nema nijednoga beneficija iako je od 1742. godine mansionar ranije spomenute mansionarije pokojnoga župnika Žufića s obzirom da nema svećenika iz linije koju je tražio oporučitelj. Osim svakodnevnoga sudjelovanja u koru obveza mu je i služiti tri mise tjedno. ${ }^{75}$ Ujedno ima i mansionariju pokojnoga suca Jakova Rovisa s obvezom dviju misa tjedno, što ih služi na tri oltara naizmjenično. Po njegovoj smrti manionarija ima prijeći u ruke najbližega svećenika obitelji Rovis, već kako je to i naznačeno u oporuci spomenutoga suca Rovisa. Preminuo je 21. rujna 1754. godine. Pokopan je sljedećega dana u župnoj crkvi. ${ }^{76}$

Don Gašpar Marinčić (Gasparo Marincich) rođen je 1705. godine, a u vrijeme vizitacije bio je svećenik već četrnaest godina. Monsinjor Grassi podijelio mu je

\footnotetext{
67 BAP-BV, Knjiga 27 (1745), 315-316.

${ }^{68}$ BAP-BV, Knjiga 27 (1745), 64.

${ }^{69}$ U zapisu o smrti stoji: aetatis suae annorum 91 circiter. HR-DAPA-429, Zbirka matičnih knjiga, MKU Žminj (1716-1774), 1. 2. 1763., 126.

${ }^{70}$ BAP-BV, Knjiga 27 (1745), 311.

${ }^{71}$ BAP-BV, Knjiga 27 (1745), 62-63.

72 BAP-BV, Knjiga 27 (1745), 312.

${ }^{73}$ BAP-BV, Knjiga 27 (1745), 317.

${ }^{74}$ BAP-BV, Knjiga 27 (1745), 13.

75 BAP-BV, Knjiga 27 (1745), 317.

${ }^{76}$ HR-DAPA-429, Zbirka matičnih knjiga, MKU Žminj (1716-1774), 98.
} 
niže redove, subđakonat i đakonat, a za svećenika ga je zaredio monsinjor Mazzoleni. Godine 1733. izabran je na mjesto kapelana kurata u Grdoselu gdje je ostao dvije godine, nakon čega je punih pet godina bio kapelanom kuratom u Gračišću, koje pripada Pićanskoj biskupiji. Uslijedio je dolazak u Žminj. ${ }^{77}$ Podložnici u kapelaniji sv. Kvirina izabrali su ga za kapelana kurata i ondje je služio dvije godine. Obitelj Žufić izabrala ga je potom za mansionara, a potvrdu je dobio od nadležne svjetovne vlasti u osobi pazinskoga kapetana. Dužnost mu je misiti dva puta tjedno na oltaru Sv. Josipa za koji se brine mansionarija što ju je osnovao pokojni župnik Ivan Krstitelj Marinčić. Odlaskom svećenika Martina Galantea u Svetvinčenat župnik Miloš izabrao ga je za kapelana kolegijalne crkve za koju ga je službu potvrdio biskup. ${ }^{78}$

Don Gasparo Dell'Osta (Gasparo Dell'Osta, Dell'Oste) ${ }^{79}$ svećenik je također ove kolegijalne crkve rođen 1699. godine. Monsinjor Grassi podijelio mu je sve redove te je u vrijeme vizitacije bio prezbiter 23 godine. Nema niti jednu crkvenu nadarbinu, ali je mansionar ili kapelan (Mansionario o sia Capellano) Bratovštine duša u Čistilištu kojega su, prema njegovim riječima, izabrali sami bratimi, a potvrdio ga je župnik. Dužnost mu je ispovijedati, služiti četiri mise tjedno za spas duša u Čistilištu te da svakoga dana služi misu prije svitanja svakoga radnog dana, a i blagdanima nakon prve ure svanuća i to na udobnost onih koji trebaju na put iz ovoga mjesta. Spomenuta je kapelanija stalna (perpetua), ali se izbor vrši svake godine u uobičajeno vrijeme. Dužnost mu je i služiti Crkvi prigodom blagdana (officiar la chiesa). Kako smo ranije napisali, u ono vrijeme svaki svećenik nije bio ipso facto ispovjednik nego je trebao dobiti posebnu dozvolu ispovijedanja. Dell'Osti je istjecala dozvola dobivena prije četiri godine, stoga moli biskupa da

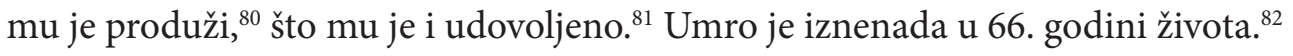
Don Petar Pucić (Pietro Pucich), također svećenik kolegijalne crkve, rođen je 1695. godine. Zadnjih 29 godina nosi kleričko odijelo, a svećenik je po rukama monsinjora Grassija od prije oko 25 godina. Nakon nekoliko godina po ređenju za svećenika izabran je za kapelana od Cerana da im služi misu u Sv. Mateju prigodom blagdana i o kvaternicama. Ovi podložnici za to mu plaćaju četvrtinu (una quartta) desetine žita i vina, što nije zapovjeđeno nego je po njihovoj dobroj volji, a iz godine u godinu varira ovisno o tome kako bude određeno prilikom izbora i potvrde koja se održava svake godine na blagdan Sv. Mateja. Ispovjednik je od 1724. godine na dalje za što ima potrebne dozvole. Nema beneficija ni man-

\footnotetext{
77 BAP-BV, Knjiga 27 (1745), 319.

78 BAP-BV, Knjiga 27(1745), 320-321.

79 Prezime Dell'Oste bilo je nazočno u Žminju tijekom 18. stoljeća. Vidi: HR-DAPA-429, Zbirka matičnih knjiga, MKU Žminj (1716-1774), 164'.

${ }^{80}$ BAP-BV, Knjiga 27 (1745), 322-323.

81 BAP-BV, Knjiga 27 (1745), 13.

${ }^{82}$ HR-DAPA-429, Zbirka matičnih knjiga, MKU Žminj (1716-1774), 23. travnja 1765., 138.
} 
sionarije. ${ }^{83}$ Dušu je predao Gospodinu u 86. godini života mjeseca siječnja 1781. godine. I on je pokopan u župnoj crkvi. ${ }^{84}$

Don Ivan Krstitelj Rovis (Giovanni Battista Rovis), imenjak i prezimenjak žminjskoga kanonika, bio je svećenik ove kolegijalne crkve, rođen 1700. godine. Svete redove dobio je po rukama monsinjora Grassija, a svećenik je bio 21 godinu. Nema beneficij, mansionariju ni kapelaniju, nego živi od vlastitih prihoda (vivo della mia entrata), a crkvi služi blagdanima. Njegova ocjena župnika je pozitivna naglašavajući da ovom kršćanskom zajednicom župnik dobro upravlja, što, kako navodi, nije bio slučaj u prošlosti. ${ }^{85}$ Prema njemu nema skandala u ovoj župi osim što se ponešto govorka o neslozi između župnika i kanonika koji se često nadvikuju u sakristiji. ${ }^{86}$ Preminuo je mjeseca ožujka 1779. godine s navršene 84 godine života te je pokopan u kolegijalnoj crkvi. ${ }^{87}$

Don Marino Bančić (Marino Bancich), svećenik ove kolegijalne crkve, rođen je oko 1689. godine. Postao je subđakon i đakon po rukama monsinjora Adelassija, a svećenik po monsinjoru Vairi. Ispovijeda zadnjih 28 godina, što dokazuje i dobivenim bulama. Mansionar je mansionarije što ju je osnovao pokojni Lovro Marinčić s obvezom mise dva puta tjedno u kolegijalnoj crkvi na oltaru Svih Svetih. Pravo izbora mansionara ima župnik, gastald Bratovštine Svih Svetih i aktualni župan. Zadnjih 27 godina služi ovoj mansionariji pri čemu mu prihodi dolaze od vinograda, nasada, zemlje i šume (vigne, piantada, terre e bosco) ${ }^{88}$ Ovozemaljski život zaključio je 7. studenoga 1761. s navršene oko 72 godine života. Pokopan je u župnoj crkvi. ${ }^{89}$

Don Ivan Žufić (Giovanni Suffich), svećenik ove kolegijalne crkve, rođen 1712. godine, zadobio je rukopoloženje po monsinjoru Mazzoleniju. Prema zapisu vizitacije zadnjih je devet godina svećenik, ali bez beneficija, mansionarije i kapelanije. Službuje kao orguljaš i za to dobiva za plaću od župljana četrdeset stari žitarica (stara quaranta), to jest jedan starić (starol) žita po kući i to je sav njegov prihod. ${ }^{90}$ Don Žufić, sin Jakovljev, oblačio se u odijelo boje akacije sa zlaćanim čarapama, što također nije bilo po kleričkoj uzanci. ${ }^{91}$ Uz orguljaša don Žufića monsijnjor

\footnotetext{
${ }^{83}$ BAP-BV, Knjiga 27 (1745), 324-325.

${ }^{84}$ HR-DAPA-861, Zbirka preslika gradiva iz arhiva i ustanova RH, DVD 5, ZM34K-135, MKU Žminj (1775-1812), 10. siječnja 1781.

${ }^{85}$ Le funzioni della chiesa vengono ben dirette sotto di lui che non era cosi per il tempo passato. BAP-BV, Knjiga 27 (1745), 326.

${ }^{86}$ (...) solamente si dice qualche cosa tra la discordia del Paroco con il Canonico Rovis che spesso fra di loro gridano in Sagrestia. BAP-BV, Knjiga 27 (1745): 327.

${ }^{87}$ HR-DAPA-861, Zbirka preslika gradiva iz arhiva i ustanova RH, MKU Žminj (1775-1812), 15. ožujka 1779.

${ }^{88}$ BAP-BV, Knjiga 27 (1745), 327-328.

${ }^{89}$ HR-DAPA-429, Zbirka matičnih knjiga, MKU Žminj (1716-1774), 120'

${ }^{90}$ BAP-BV, Knjiga 27 (1745), 329-330.

${ }^{91}$ BAP-BV, Knjiga 27 (1745), 306, 332.
} 
Negri zamjećuje orgulje u župnoj crkvi opisujući ih kao lijepe i dobre..$^{92} \mathrm{U}$ eri glasovitoga izrađivača orgulja Petra Nakića, koji je autorom onih u Svetome Lovreču (1735.?), prijašnjoj Miloševoj župi, kao i orgulja u porečkoj bazilici (1759.), ${ }^{93}$ biskupovo isticanje žminjskih orgulja nije zanemariv podatak. Promatrajući ostale župne crkve u austrijskome dijelu Porečke biskupije, Žminj je po pitanju orgulja također prednjačio, to jest imao ih je među prvima; spominju se već uz one pazinske sredinom 17. stoljeća. ${ }^{94}$ Don Žufić će naslijediti Miloša na mjestu žminjskoga župnika 1754. godine te će u toj službi ostati do smrti u studenome 1776. godine..$^{95}$

Don Stjepan Žufić (Steffano Suffich), svećenik ove kolegijalne crkve, godine 1745. imao je oko 35 godina. Po monsinjoru Grassiju zadobio je svete redove, a za svećenika je zaređen po rukama monsinjora Mazzolenija. Svetu misu služi zadnjih jedanaest godina, a da nema beneficija, mansionarije ni kapelanije. Živi od vlastitih prihoda. Službuje u ovoj crkvi kao jednostavan svećenik sudjelujući u svim službama. ${ }^{96}$

Dakle, u Žminju je 1745. godine bilo aktivno jedanaestoro svećenika na 2442 župljana; drugim riječima, u prosjeku na 222 stanovnika dolazi jedan svećenik, što je brojčani odnos koji je vrijedio za, primjerice, biskupiju Viviers u Francuskoj krajem 17. stoljeća. ${ }^{97}$ Usporedbe radi, krajem toga istog stoljeća (1788.) u ovoj župi bilo je djelatno sedam svećenika, ${ }^{98}$ što je pad broja klerika za $36 \%$ u vremenskome odmaku od 35 godina. Zacijelo se radi o tendenciji opadanja broja klerika krajem 18. stoljeća karakterističnom i za prostor venecijanske Istre. ${ }^{99} \mathrm{Ta}-$ kva brojnost svećenstva razumljiva je s obzirom na to da je riječ o vremenu katoličkoga trijumfa, što je trajalo od turskoga neuspjelog zauzimanja Beča (1683.) pa do smrti Marije Terezije (1780.), to jest tada nastupajućih radikalnih reformi

\footnotetext{
${ }_{92}$ Elvis Orbanić, Elena Uljančić Vekić, "Prilog proučavanju crkvene i društvene povijesti Žminjštine u prvoj polovici 18. stoljeća”, Libri žminjski, sv. 1, ur. Slavko Krajcar (Žminj: Katedra Čakavskog sabora Žminj, 2008), 55.

${ }^{93}$ Giuseppe Radole, “Gli organi nelle chiese istriane”, AMSI 16 (1968), LXVIII della Racolta: 129, 136.

${ }_{94}$ Žminj: Sia accomodato l'organo, et provisto d'Organista, BAP-BV, Knjiga 9 (1658), 9; Pazin: Vi e’ anco l'organista, che e' Prete forestiero, et Pre Zvanne Calcich Capellano della Schola del Rosario. (BAP-BV, Knjiga 10 (1663), 208. Petronio spominje da su u Žminju orgulje s devet registara. Prospero Petronio, Memorie sacre e profane dell'stria (Trieste: Tip. G. Coana, 1968), 245.

${ }^{95}$ Pokop je izvršio Ignacije Buzetski, pazinski prepozit. HR-DAPA-861, Digitalni preslici matičnih knjiga, MKU Žminj (1775-1812), 30. studenoga1776.

${ }_{96}$ BAP-BV, Knjiga 27 (1745), 331-332.

${ }^{97}$ Godine 1693. u biskupiji Viviers na 220 stanovnika bio je jedan svećenik, a 1774. godine jedan je svećenik bio na 259 stanovnika. Alain Molinier, "Parroci e parrocchiani della Controriforma", u: Storia vissuta del popolo cristiano, ur. Jean Delumeau (Torino: Società editrice internazionale, 1985), 590.

${ }^{98}$ Elvis Orbanić, prir., Ignazio Gaetano de Buset: visita spirituale del 1788 in Istria /Ignacije Kajetan Buzetski: duhovna vizitacija iz 1788 u Istri (Citta' del Vaticano: Associazione archivistica ecclesiastica, 2016), 252-254.

${ }^{99}$ Egidio Ivetic, La popolazione dell'Istria nell'eta' moderna. Lineamenti evolutivi (Trieste; Rovigno: Unione italiana - Fiume; Univerista' popolare di Trieste, 1997), 235.
} 
pod Josipom II. ${ }^{100}$ Promotrimo li prezimenske oblike ${ }^{101}$ žminjskih klerika, zapažamo brojčanu prevagu hrvatskih prezimena $(77 \%)^{102}$ u odnosu na talijanske oblike (23\%), koja je, kako ćemo pokazati niže, odraz sredine njihova djelovanja $\mathrm{u}$ etničkome, protonacionalnom smislu. Valja napomenuti kako narodnosni plural karakterizira Istru u cjelini tijekom ranoga novovojekovlja gdje Žminj pruža (ovdje predstavljenu) antroponimijski krnju sliku te sveistarske stvarnosti ujedno svjedočeći brojčanu dominaciju hrvatskoga seoskog življa i njihovoga suživota s talijanskim stanovništvom. ${ }^{103}$ Raščlanjena vrela ne bilježe nikakve napetosti kada su odnosi ovih dvaju kulturnih i etničkih krugova u pitanju. Međusobne trzavice su rijetke, a pojavljuju se kao nesklad karaktera subraće i kolega koje je prst sudbine postavio djelovati u istome kaptolu. Razvidno je to na primjeru kontrapozicija župnik Miloš - kanonik Rovis, što je - sudeći po nekim drugim vrelima - poprimilo razinu obiteljske razmirice. ${ }^{104}$

Tablica 3. Svećenici aktivni u župi Žminj 1745. godine ${ }^{105}$

\begin{tabular}{|l|l|}
\hline Ime i prezime & Položaj \\
\hline Sebatijan Miloš & župnik i kanonik \\
\hline Ivan Krstitelj Rovis & kanonik \\
\hline Gašpar Marinčić & kapelan kurat / mansionar \\
\hline Marin Žufić & $\begin{array}{l}\text { kapelan kurat / bez beneficija / kapelan } \\
\text { kurat }\end{array}$ \\
\hline Gasparo dell'Oste & kapelan Duša u Čistilištu \\
\hline Franjo Rovis & mansionar \\
\hline Marin Bančić & mansionar \\
\hline Petar Pucić & kapelan kurat u Ceru (dragovoljno plaćen) \\
\hline Ivan Krstitelj Rovis & svećenik s vlastitim prihodom \\
\hline Ivan Žufić & orguljaš \\
\hline Stjepan Žufić & svećenik s vlastitim prihodom \\
\hline
\end{tabular}

\footnotetext{
${ }^{100}$ Jean Bérenger, "The Austrian Church”, u: Church and society in Catholic Europe of the eighteenth century, ur. William J. Callahan, David Higgs (Cambridge; New York: Cambridge University Press, 2008), 88.

${ }^{101}$ O hrvatskim prezimenima u Istri vidi: Petar Šimunović, Hrvatska u prezimenima (Zagreb: Golden marketing; Tehnička knjiga, 2008), 157-166.

${ }^{102} \mathrm{O}$ nazočnosti hrvatskih etnika na Žminjštini već u srednjemu vijeku kazuje u smislu arhivskoga dokumenta i Istarski razvod (Josip Bratulić, "Žminj u Istarskom razvodu”, u: Libri žminjski, sv. 2, ur. Slavko Krajcar (Žminj: Katedra Čakavskog sabora Žminj, 2008), 55-63) kao što u epigrafici to čine glagoljski grafiti uparani na unutrašnjim zidovima crkve Sv. Trojice i Sv. Antuna Opata odražavajući hrvatski jezik tijekom 15. i 16. stoljeća. Branko Fučić, Glagoljski natpisi (Zagreb: Jugoslavenska akademija znanosti i umjetnosti, 1982), 387-389.

${ }^{103}$ Glogorica vjerojatno predstavlja, kada je povijest etniciteta u pitanju, najsrodniju sredinu Žminju. Nju je iz narodnosnoga očišta maestralno raščlanio Miroslav Bertoša. Miroslav Bertoša, Etos i etnos zavičaja (Pula; Rijeka; Rovinj: Čakavski sabor; Istarska naklada; Otokar Keršovani; Edit, Centro di ricerche storiche, 1985), 177-253.

${ }^{104}$ Detaljnije o tome vidjeti u poglavlju ovoga članka: Neprilični nećak.

${ }^{105}$ BAP-BV, Knjiga 27 (1745), 95. i passim.
} 
Tablica 4. Imena žminjskih bogoslova (chierici) 1745. godine ${ }^{106}$

\begin{tabular}{|l|l|}
\hline Ime i prezime & Položaj \\
\hline Paškvalin Žagrić & franjevac minorit \\
\hline Josip Križanac & franjevac minorit \\
\hline Martin Staver & franjevac minorit \\
\hline Antun Rovis & s dopuštenjem talara bez tonzure \\
\hline
\end{tabular}

\section{O materijalnoj osnovi klera}

Župnik, kanonik i kapelan kurat bili su nadarbenici (beneficijari), što znači da su imali uz crkvenu službu, to jest duhovne obveze, ujedno od Crkve dodijeljen izvor stalnih prihoda za svoje uzdržavanje. ${ }^{107}$ Ostale su kapelane bili plaćali oni koji su imali pravo njihova izbora, što su bile bratovštine ili mjesne kapelanije, $s$ time da - primjerice kapelanija Sv. Mateja - nije morala plaćati svome kapelanu, ali to čini dragovoljno. Nadalje, u Žminju susrećemo i posebne zadužbine poznate pod imenom mansionarija. Njih su osnivali aktom testamenta svećenici i laici na način da bi odredili određene svojine kao izvor uzdržavanja za neke oltare kao i svećenike koji na njima imaju misiti. Biranje svećenika-mansionara ovisilo je o volji oporučitelja.

Nadalje, žminjski klerici imali su pravo na četvrtinu desetine svih vrsta požnjevenih žitarica žminjskoga kòmuna kao i četvrtinu desetine vina koju je ubirala državna vlast kako je to navedeno u Pazinskome urbaru iz 1578. godine, ${ }^{108}$ na snazi i tijekom 18. stoljeća, ${ }^{109}$ a što potvrđuju i svećenici svojim iskazima 132 odnosno 167 godina nakon donošenja Urbara.

Tako župnik Sante Rovis godine 1710. izjavljuje kako se njegov beneficij sastoji od četvrtine desetine pšenice, ostalih žitarica i vina, čemu nadodaje da mu pripada i od životinja desetina (decimali) jaganjaca i kozlića što ih dijeli sa žminjskim kanonikom. ${ }^{110} \mathrm{Za}$ razliku od Rovisa Miloš će 1745. godine biti nešto detaljniji u opisivanju svojih prihoda koji su se sastojali od četvrtine ili primicija desetina. Njih plaćaju seljaci ovoga područja na svetkovinu zaštitnika župe sv. Mihovila. Radi se o žitaricama, graia(?), krmi, vinu, janjadi, što se sve dijeli na tri dijela, to jest jedan dio ide njemu kao župniku, potom drugi dio ide kanoniku i treći

\footnotetext{
${ }^{106}$ BAP-BV, Knjiga 27(1745), 95.

${ }^{107}$ Riječ je o beneficium ecclesiasticum kao pravu pobiranja stalnih crkvenih dohodaka određenih za pojedinu crkvenu službu. Zlatko Herkov, "beneficium”, u: Financijsko-pravni rječnik feudalne epohe Hrvatske sv. 1 (Zagreb: Jugoslavenska akademija znanosti i umjetnosti, 1956), 103.

${ }^{108}$ Vjekoslav Bratulić, “Urbari Pazinskog feuda (XVI stoljeća)”, VHARP 8-9 (1963-1964): 181.

${ }^{109}$ Trajao sve do ukinuća feudalizma u Austriji. De Franceschi, Storia documentata, 172.

${ }^{110}$ BAP-BV, Knjiga 17 (1710), 101.
} 
dio porečkome biskupu, koji je od davnih vremena titularni žminjski kanonik. ${ }^{111}$ Žminjski župnik tada je uz navedena dobra dobivao još i prvinu sira (la primizia del formagio) i ostaloga, što je na godišnjoj razini moglo iznositi vrijednost od oko dvjesto dukata. ${ }^{112}$

Osim prihoda ova župa imala je i rashode, to jest davanja na koja je bila obvezna prema državi i višim crkvenim vlastima. Kako saznajemo iz zapisnika vizitacije u četrdesetim godinama 18. stoljeća, župnik je svake godine plaćao Ljubljanskoj provinciji (Provincia di Lubiana) dvanaest njemačkih fjorina (fiorini alemani) na račun kanoničke prebende i druga dva fjorina na račun papinskoga poreza (Tassa Pontificia), što se plaća svakih pet godina. Dodatno plaća i katedratik ${ }^{113} \mathrm{u}$ iznosu od četiri lire godišnje. Kako u mjestu ne postoji župna kuća u kojoj bi župnik mogao stanovati, ovaj je trebao plaćati i najam za posebnu kuću. Naime, župna kuća tada je bila srušena i u nju jedva da je stala odjeća. ${ }^{114}$

U ovoj župi 1745. godine zatječemo dva svećenika od njih jedanaest koji su živjeli isključivo od vlastitih prihoda, to jest nisu imali nadarbinu, mansionariju ni ikakvu naknadu za svećeničku službu pa su zacijelo živjeli od rada u poljoprivredi. Pedesetak godina prije opisanoga stanja u Žminju slovenski polihistor Valvasor predočava nam upravo takvu sliku o istarskim klericima navodeći: (...) prije podne čeka ih dužnost njihove duhovne službe te čitaju misu, a poslije podne toliko se trude oko svjetovnih poslova te idu kao i drugi ljudi na posao pa rade pošteno oznojena lica. ${ }^{115}$

Kao jedno u nizu otvorenih historiografskih pitanja ostaje za istražiti procedure popunjavanja kleričkih pozicija na ovim prostorima s njihovim mogućim posebnostima, a to znači i način stjecanja ponekad unosni(ji)h položaja unutar crkvene hijerarhije na mikrorazinskoj strukturi župe i zbornoga kaptola. Time bismo dobili potpuniji uvid u način funkcioniranja društva središnje Istre u crkveno-vjerskoj i gospodarskoj dimenziji te bismo ga mogli usporediti s ostalim katoličkim krajevima. Stjecanje kanonikata sa šesnaest godina, kako nam pokazuje primjer Žminjca Rovisa, zasigurno nije bila izolirana pojava, što je tim više poticaj za neka opsežnija istraživanja.

\footnotetext{
${ }^{111}$ Il mio reddito consiste nella qaurta o primizia delle decime che si pagano da questi Villici e Territoriali. BAP-BV, Knjiga 27 (1745), 304.

${ }^{112}$ BAP-BV, Knjiga 27 (1745), 305.

${ }^{113}$ Cattedratico, to jest cathedraticum je census annuus episcopo praestandus odnosno biskupska daća, katedratik. Usp. Lexicon latinitatis medii aevi Iugoslaviae, sv. 1 (Zagreb: Editio Instituti historici Academiae scientiarum et artium Slavorum meridionalium, 1973), 194.

${ }^{114}$ (...) ha l'aggravio di pagar l'affitto della Casa ogni anno non essendovi Casa Parochiale da abitare, mentre la Casa Parochiale e affatto dirocata, che appena vi sono le Vestigia. BAP-BV, Knjiga 27 (1745), 305.

${ }^{115}$ Zvonimir Sušić, "Valvasor o Istranima. Preveo s njemačkog originala i bilješke napisao dr. Zvonimir Sušić”, Dometi 5 (svibanj 1970): 88.
} 


\section{Procesije, hodočašća i slavlja}

$\mathrm{Na} Z \check{m}$ injštni se sredinom 18. stoljeća održavao niz procesija tijekom nagodine. ${ }^{116}$ Njihove putanje bile su neovisne o tadašnjim državnim i biskupijskim granicama. Tako su na Dan sv. Viktorije Mučenice ${ }^{117}$ Žminjci hodočastili u obližnji, no ipak državno prekogranični, Svetvinčenat na poklon zemnim ostatcima ove ranokršćanske mučenice, koje je iz Rima donio Antonio Grimani, vlasnik feuda Svetvinčenat. ${ }^{118}$ Njezino javno čašćenje započelo je 1. lipnja 1670. godine da bi 1709. godine uz veliko slavlje prenijeli tijelo sv. Viktorije s glavnoga oltara na kojemu je do tada počivala na pokrajnji oltar koji je onomad bio posvećen Bezgrješnomu Začeću. ${ }^{119}$ Žminjci su zasigurno pratili navedene promjene u susjednoj im župi te revno častili njezine relikvije.

Nedjelju poslije blagdana Tijelova pješačili su u Rovinj častiti zemne ostatke sv. Eufemije. Naime, postojala je tradicija da svake godine - počevši do blagdana Duhova - svake sljedeće nedjelje mnoge istarske župe u procesiji posjete i crkvu Sv. Eufemije, kako one u blizini, ali i one udaljenije od Rovinja. Ta je praksa trajala sve do 1810. godine kada su ove procesije u Rovinj prestale, osim župljana Rovinjskoga Sela, koji su je održavali sve do sredine 19. stoljeća. ${ }^{120}$

Unutar austrijske Istre hodočastilo se u petak nakon blagdana Uzašašća Gospodinova u procesiji u Pićan ili u Sveti Petar u Šumi; najvjerojatnije varirajući spomenute ciljeve hodočašća iz godine u godinu. Razlozi pokretanja ovih procesija nisu nam poznati, no Pićan je bio sjedište biskupije s katedralom za koju se izrijekom spominje kao cilj procesije, a Sveti Petar u Šumi - osim što je samostansko dobro - ujedno je i središte hodočašća kao takav navlastito ojačan i događajem koji se zbio na Badnjak 1721. godine. Naime, tada je jedan pavlin opazio (...) da lice blažene Djevice Čestohovske na velikom oltaru suzi (...), što je pokrenulo hodočašća i utjecanja za nebesku pomoć. Naravno da su i Žminjci sudjelovali u toj pobožnosti. Od rijetkih podataka možemo izdvojiti onaj iz veljače 1723. godine kada se u Sveti Petar u Šumi došao zahvaliti za svoje ozdravljenje žminjski građanin Ivan Rovis u pratnji jednoga svećenika. Bolovao je zadnja tri mjeseca te mu je, učinivši zavjet Blaženoj Djevici u samostanskoj crkvi, povraćeno zdravlje. ${ }^{121}$

\footnotetext{
${ }^{116}$ Le processioni ex votto. Domenica infra corpus Domini à Rovigno. Die veneris Rogationum post Ascensionem à Pedena overo a S. Pietro delle Selve. Die Diue Victorię à San Vincenti. In Parochia ogni Domenica prima del Mese di Santissimo Rosario. Ogni terza Domenica col Santissimo per il Luoco ambe due Processioni. Le Rogacioni per le Chiese campestre. BAP-BV, Knjiga 27 (1745), 100.

${ }^{117}$ Sv. Viktorija Mučenica slavi se 10. srpnja. Italija. EU, pristup ostvaren 30. svibnja 2016., http://www. santiebeati.it/dettaglio/90643

${ }^{118}$ Grimanijevi su bili vlasnici feuda Svetoga Vinčenta od 1561. do kraja feudalizma. Gregorio De Totto, "Feudi e feudatari nell'Istria veneta", AMSI 51-52 (1939 - 1940): 66, 88.

${ }^{119}$ Ivan Milovan, Savičenta: jučer, danas (Umag: Tipografija Umag, 1975), 28.

${ }^{120}$ David Di Paoli Paulovich, Cosi' Rovigno canta e prega a Dio (Rovigno: Centro di richerche storiche; Unione Italiana; Universita popolare, 2011), 854.

${ }^{121}$ Dragutin Nežić, "Čestohovska Gospa u Sv. Petru u Šumi. Godine 1721. prosuzila njezina slika", Ladonja (Pazin), lipanj 1987., 8; BAP-BV, Knjiga 27 (1745), 537.
} 
U mjesecu listopadu kada se slavila velika pobjeda kršćanske flote protiv Turaka, znamenite Lepantske bitke iz 1571. godine, obavljala se procesija svake nedjelje, a svake treće nedjelje po župi se u procesiji nosilo Presveto.

Uobičajene su bile i procesije za prosnih dana, koje su se izvodile posjećujući poljske crkve, ${ }^{122}$ što je vjerska praksa dokinuta početkom 19 . stoljeća, no ubrzo je vraćena zbog negodovanja vjernika. ${ }^{123}$

Od svetaca u Žminju posebno se štovala sv. Foška i to prema liturgijskome kalendaru koji je bio u uporabi od najstarijih vremena za čitavu Akvilejsku patrijaršiju, a time i Porečku biskupiju koja joj je pripadala. ${ }^{124}$

Tijekom takozvanih duhovno jakih vremena, to jest korizme i došašća, u katedralu i kolegijalne crkve dolazili bi posebno pozvani propovjednici i tumačili Riječ Božju. ${ }^{125} \mathrm{Na}$ tu je nakanu žminjski župnik svake godine zajedno sa županom, sucima i kamerlengom ${ }^{126}$ odlučivao o izboru korizmenoga propovjednika. Ovaj je bio plaćen s deset dukata i dva spuda žita i to na način da je jedan dio plaćala općina, drugi dio Crkva, a treći dio sam župnik. ${ }^{127}$ Posebno pozvani propovjednici za duhovno snaženje pastve tijekom korizme i Adventa na Žminjštini bili su karakteristika ovoga kraja i u prethodnome 17. stoljeću te su dolazili i izvan Istre. ${ }^{128}$ Žminjci su 1745. godine u vlastitoj župi imali na raspolaganju sveukupno devetnaest crkava od kojih je ona posvećena sv. Augustinu bila juspatronat baruna Brigida, vlasnika posjeda Krajcarbreg kraj Žminja. ${ }^{129}$ U župnoj crkvi bilo je - osim glavnoga oltara posvećenoga sv. Mihovilu - još devet oltara među kojima je oltar sv. Josipa juspatronat obitelji Marinčić, a oltar sv. Antuna Padovanskoga juspatro-

\footnotetext{
${ }^{122}$ BAP-BV, Knjiga 27 (1745), 100.

${ }^{123}$ Porečka biskupska kurija zabranila je 1835. godine obavljanje prosnih dana po poljima ograničivši ih samo na grad. Bernardo Benussi, Storia documentata di Rovigno (Trieste: Unione degli Italiani dell' Istria e di Fiume; Universita popolare di Trieste, 1977), 192.

${ }^{124}$ Grah, "Pazinski kraj”, 214.

${ }^{125} \mathrm{Grah}$, “Izvještaji porečkih biskupa”, 34 .

${ }^{126}$ Kamerlengo (camerlengo) je u venecijanskome dijelu Istre bio službenik koji je nadzirao ubiranje javnih prihoda. Giuseppe Boerio, Dizionario del dialetto veneziano, Ristampa anastatic (Milano: Aldo Martello editore, 1971), 121. Jelinčić, primjerice, u mletačkoj općini Novigrad kamerlenga naziva i općinskim blagajnikom. Jakov Jelinčić, "Novigradska kancelarija (Istarski Novigrad) u XVIII. st. do pada Venecije (1797.)" (magistarski rad, Sveučilište u Zadru, 1976), 10. I inače ga se u literaturi tumači kao općinskoga blagajnika, javnoga službenika (tesoriere del comune, amministratore pubblico, dignita' tra gli elettori dell'impero germanico), Carlo Battisti, Giovanni Alessio, "Camerlengo", u: Dizionario etimologico italiano, vol. 1 (Firenze: Barbèra 1975), 697.

${ }^{127}$ Ogni anno li Signori Pievani Predecesori passavano corrispondenza col Supano, Giudici, e Camerlengo nellelletione del Predicatore Quadragesimale e la Communita' corisponde, e corrisponda la stabilita portione di Ducati Dieci, e Formenti n. 2, e una parte le Chiese l'altra il Paroco... BAP-BV, Knjiga 27 (1745), 626. ${ }^{128}$ Alojz Štoković, “Žminjske bratovštine”, u: Libri žminjski, sv. 2, ur. Slavko Krajcar, 89. Žminj: Katedra Čakavskog sabora Žminj, 2008.

${ }^{129}$ O obitelji Brigido vidi: Slaven Bertoša, “Brigido, feudalna plamićka obitelj”, u: Istarska enciklopedija (Zagreb: Leksikografski zavod Miroslav Krleža, 2005), 100; Dario Alberi, Istria: storia, arte, cultura (Trieste: Lint, 1998), 1484-1485.
} 
nat obitelji Bianchi. ${ }^{130}$ Sakrament Svete potvrde u pravilu dijeli biskup, no kako nije redovito uspijevao izvršavati svoju obvezu vizitacije, tako je upravo ovom prigodom (1745.) podijelio krizmu. ${ }^{131}$ Jezik liturgije nije posebno istican tijekom vizitacija iz prve polovine 18. stoljeća tako da smo zakinuti za izravne saznanja po tome pitanju. Dakle, jedanaest žminjskih svećenika obavljalo je ključni dio svoga duhovnog poziva, što se opredmećuje u slavljenu Euharistije na oltarima sveukupno tada postojećih devetnaest crkava župe.

\section{Neprilični nećak}

U kolegijalnoj crkvi postojale su kasice ispred pojedinih oltara u koje su župljani ubacivali milostinju. U više je navrata 1739. godine župnikov nećak Ivan Gramaticopoli (Giovanni Gramaticopoli) ${ }^{132}$ protivno želji bratima praznio te kasice na način da bi ključeve uzeo iz stana svoga strica i župnika Miloša. Na takav je način uspio isprazniti kasicu što je stajala ispred kapele Duša u Čistilištu, a tako i onu ispred kapele Presvetoga Ružarija.

Dana 27. lipnja spomenute godine to je nedjelo ponovio, a razbio je one kasice za koje nije imao ključ. Tim je činom zacijelo prevršio mjeru strpljenja bratima te je bio prijavljen. Sve je opisano župnikov nećak priznao sucu u Pazinu, a očevidac toga neprimjerenog ponašanja Ivan Debeljuh (Giovanni Debegliuch) isto je i posvjedočio. Martin De Terzi kao pazinski kapetan bio je i razboriti sudac u ovome slučaju vodeći računa o mladosti počinitelja (atesa la di lui giovenil età) osudivši ga na tri dana zatvora na kruhu i vodi te deset udaraca svakoga zatvoreničkog dana. ${ }^{133}$ Nestalu milostinju, kao i naknadu za razbijene kasice te troškove sudskoga procesa, presuđeno je da nadoknadi njegova majka. Primijetit ćemo da je od počinjenja krađe (27. lipnja) do presude (7. srpnja) ${ }^{134}$ proteklo ukupno deset dana.

Plod ovdje ukratko opisanoga sudskog procesa i uopće lošega iskustva nagnao je odgovorne osobe Žminjštine na drugačije postupanje, to jest stroža pravila u postupanju s milostinjom bratovštine Duša u Čistilištu. S dopuštenjem civilnih

\footnotetext{
${ }^{130}$ Orbanić, Uljančić Vekić, “Prilog proučavanju”, 53-61.

${ }^{131}$ Orbanić, Uljančić Vekić, “Prilog proučavanju”, 53, 56, 59.

${ }^{132}$ Antonija Gramaticopolija, stanovnika Žminja (dimorante in Gimino), optužio je Vid Franjul, pazinski prepozit i vanjski vikar, za prijavljivanje žminjskoga kanonika Ivana Krstitelja Rovisa porečkome biskupu umjesto da je to učinio u Pazinu vanjskome vikaru kako nalažu pravila civilne vlasti. Arhiv Republike Slovenije - Reprezentanca in Komora za Kranjsko, fasc. XIX, XX, 7. rujna 1747. Dominus Antonius Gramaticopolo je umro navršivši oko sedamdeset godina 13. kolovoza 1757. godine (HR-DAPA-429, Zbirka matičnih knjiga, MKU Žminj (1716-1774), 105’). Moguće je da je Antonio bio u rodbinskoj vezi sa spomenutim Ivanom, koji je predmet ovoga poglavlja. Na prezime Gramaticopolo ne nailazimo u žminjskoj Matičnoj knjizi krštenih za razdoblje od 1662. do 1700. godine iz čega proizlazi da je ta obitelj došla u Žminj tijekom prve polovice 18. stoljeća.

${ }^{133} \mathrm{O}$ položaju maloljetnika kao počinitelja kaznenoga djela vidjeti: Ante Carić, Mlađe osobe u kaznenom pravu (počinitelji i žrtve) (Zagreb: Pravni fakultet, 2002), 1-3, 8-9.

${ }^{134}$ BAP-BV, Knjiga 27 (1745), 624, 628.
} 
vlasti bratimi spomenute bratovštine napravili su kasicu s tri brave i tri različita ključa. Od ta tri ključa jednoga su nudili župniku, no ovaj ga, očevidno zbog netom proteklih nemilih događaja, nije htio primiti pa su ključ predali kanoniku. Drugi ključ uručili su županu, a treći je dobio gastald bratovštine. Dogovor je bio da se kasica s milostinjom otvori svakoga mjeseca te da se s ondje skupljenim sredstvima isplate mise za duše $\mathrm{u}$ Čistilištu. ${ }^{135}$

\section{Spor oko izbora kapelana bratovštine i kapele Duša u Čistilištu}

Pobožni Žminjci podigli su kapelu kolegijalne crkve posvećene u čast Žalosne Gospe od pomoći dušama u Čistilištu. S porastom milostinje bratimi su, da bi još više bili od pomoći dušama u Čistilištu, izabrali jednoga svećenika za kapelana koji je trebao misiti svakoga jutra nakon zvonjave Zdravo Marijo, što ju je obavljao žminjski zvonar Matija Križanac zvani Blagdan (Mattio Crisanaz detto Blagdan). ${ }^{136}$ Inače, kada je u pitanju zvonjenje, ovdje je bio običaj da veliko zvono župne crkve zvoni kao obavijest o preminuću nekoga od žminjskih svećenika, župana, sudaca, a ponekad i neke glave obitelji (Capo di famiglia) ako bi ovaj donirao jedan dukat glavnoj crkvi. ${ }^{137}$ Upravo je prilikom vizitacije 1745. godine monsinjor Negri blagoslovio tri zvona župne crkve i posvetio ih: veliko u čast sv. Mihovila, srednje u čast sv. Barbare i maleno u čast sv. Tri kralja. ${ }^{138}$

Spomenuta rana misa bila je potrebna za radnike koji bi u rano jutro išli put polja, obrtnike i putnike. Kapelan je bio plaćen sa šezdeset dukata, a birali su ga zajedno žminjski kaptol, župan, suci i bratimi. I tako je bilo neko vrijeme, međutim, dana 25. siječnja 1740. dolazi do spora između župnika Miloša i bratima. Ovaj je umjesto don Franje Rovisa, koji je dugo vremena bio kapelanom bratovštine, svećenik ćudoredan i dobra ponašanja, svojevoljno i bez suglasnosti bratima imenovao na tu službu don Gaspara Dell'Osta. Vanjski vikar iz Pazina, kao biskupov opunomoćenik za austrijski dio Porečke biskupije, udarit će kaznom izopćenja don Dell'Osta ako bude slavio misu na tome oltaru, svjestan da će bratimi prestati davati milostinju zbog uzurpiranja njihovoga prava izbora, čime će duše u Čistilištu ostati bez potrebne duhovne pomoći koja se očitovala misama na tu nakanu. Dakako da su bratimi izložili svoje stajalište župniku Milošu, no bez rezultata. Ni svjetovnoj pravdi nije uspjelo privoljeti župnika na popuštanje. Prema župnikovim prokazivačima poteškoće u Žminju su brojne do mjere propadanja crkvenih objekata; to uključuje krovove koje prijeti urušavanjem, a zbog nedostataka sredstava crkve su ostale bez svijeća te nalikuju pećinama: (...) povere Chiese gia redote in spelonche prive di candelle d'illuminazione, e li tetti minaciano ruina (...). Jedan od

\footnotetext{
${ }^{135}$ BAP-BV, Knjiga 27 (1745), 624.

${ }^{136}$ BAP-BV, Knjiga 27 (1745), 410, 483.

${ }^{137}$ (...) se pero' fa' la carita' d'un Ducato alla Chiesa Maggiore. BAP-BV, Knjiga 27 (1745), 626.

${ }^{138}$ Orbanić, Uljančić Vekić, “Prilog proučavanju”, 56.
} 
župnikovih krimena, povodeći se bratimima, jest i taj što ovaj daje pismenim laicima vođenje bratovštinskih knjiga (secolari de pena da' Libri di confraterne). Kako ni laici ni klerici ne smiju prigovarati (...) senza che alcuno possa aprir la bocca si che secolari che sacerdoti (...), stoga mole presvijetloga kapetana da on vlašću i autoritetom suca zabrani gastaldu isplatu plaće novome kapelanu kao i da potvrdi bratimima pravo biranja svoga kapelana Kapele od Čistilišta, koje imaju već jako dugo (che gia tanto tempo habbiamo). Prijavu pazinskom kapetanu podnijeli su župan, suci i bratimi Bratovštine Kapele od Čistilišta. ${ }^{139}$

Zasebnim dekretom donesenim prigodom svoga posjeta Žminju 3. veljače 1740. Martin De Terzi, kapetan Pazinske knežije, taj plemić Svetoga Rimskog Carstva i doktor obaju prava, zabranio je Furisu, gastaldu Bratovštine Duša u Čistilištu, pod prijetnjom plaćanja iz vlastitih sredstava (ex proprijis) i hapšenja ako bude davao plaću ili isplaćivao bilo što drugim kapelanima osim onome kojega su izabrali župan, sudac i subraća jer ovi imaju jus eligendi. Iz toga dekreta saznajemo da je riječ o pravilu kojega se pridržavaju u svim ostalim bratovštinama. ${ }^{140}$ I tako je nemila epizoda uzurpacije prava izbora kapelana Bratovštine Duša u Čistilištu od župnika Miloša zaključena odlukom u korist bratima.

\section{Pogledi iz očišta laika}

U ovoj malenoj feudalnoj sredini viđeniji laici tih godina bili su politički predstavnici kòmune i sudac tako da su godine 1745. to bili kamerlengo Ivan Krizostom Kramer (Giovanni Crisostomo Cramer q. Michael), star 49 godina, aktualni župan Josip Žufić (Giuseppe Suffich), star 45 godina, nekadašnji župan Jakov Žufić (Giacomo q. Marino Suffich), star 62 godine i sudac Ivan Krstitelj Rovis (Giovanni Battista Rovis), star 55 godina. ${ }^{141}$ Istaknuti laici, poput netom navedenih, unutar kòmuna redovito su uživali povjerenje vizitatora i kao takvi bili ispitani o stvarima vjere i morala. Promatrano sadržajno, gotovo je sva vizitatorova pozornost bila usmjerena prema kleru, zato su i ispitivanja spomenutih laika tako koncipirana.

Preko kamerlengovih svjedočenja pred monsinjorom Negrijem dobivamo potvrdu o postojanju lođe u Žminju. Pod njezinim krovom, što je bio običaj u primorskim gradovima, objavljivale su se i čitale odluke i obavijesti. ${ }^{142}$ Osim ovih formalnih sastanaka lođa je bila i mjesto javne razbibrige i opuštanja. Da je tomu

\footnotetext{
${ }^{139}$ BAP-BV, Knjiga 27 (1745), 630-631. Nema nadnevka na dokumentu.

${ }^{140}$ BAP-BV, Knjiga 27 (1745), 634.

${ }^{141}$ Potonji je očevidno osoba istoga imena i prezimena kao i tadašnji kanonik. Najnoviji rad koji obrađuje laički svijet na prostru Porečke biskupije u kontekstu biskupskih vizitacija vidi u: Elena Uljančić Vekić, "Župnici, župani i suci u zapisnicima pastoralnih vizitacija 17. i 18. stoljeća: primjer Žbandaja i Vabrige", Acta Histriae, 17 (2009): 251-276.

142 Šonje, Žminj i Žminjština, 6-7.
} 
tako kazuje i Kramer spominjući podatak da je župnik viđen mnogo puta kako se pojavljuje na trgu i ispod javne lođe bez kote, a s vunenom kapom konjski smeđe boje, bez crkvenjačke odjeće, u košulji i bijelim hlačama (čarapama), a ponekad u zelenome odijelu zadržavajući se ispod lođe u kartaškim igrama s pukom. Igrao je i moru u dućanu s čuđenjem naroda. ${ }^{143}$ Naime, nakon krize klera u 15. stoljeću Tridentski koncil (1545. - 1563.) želio je oblikovati model dobroga svećenika, o čemu onodobna literatura naglašava kakav to svećenik treba biti. Zato papa Siksto V. (1589.) naređuje za klerike nošenje talara čemu je u praksi, kako nam zorno pokazuje i ovaj primjer, bilo otpora. Koncil je zabranio klericima pohađanje konoba, odlaženje u lov i igre na sreću. Nastojalo se, dakle, na distanciranju od laičkoga zabavljanja kako klerici ne bi došli u napast. Tonzura i način odijevanja tome su načelu trebali dati jasan znak prepoznavanja. ${ }^{144} \mathrm{U}$ ovome žminjskom slučaju župnik očevidno nije na tragu spomenutih crkvenih preporuka. K tome, prema predočenome opisu na njemu prepoznajemo tradicijsku nošnju. Dok su Žminjci kao pripadnici subetničke skupine poznate kao Bezaki nosili brageši, to jest smeđe suknene hlače što dopiru do pola lista i nisu priljubljene uz nogu, Vlasi, doseljenici iz mahom hrvatskih krajeva pod turskom opasnošću koji su naseljavali u pravilu mletački dio Istre, nosili su benevreke, što su uske hlače od bijeloga sukna koje je don Ravasini preveo biskupu kao calze bianche. Neizostavan tradicijski odjevni predmet za muškarce, također uočen na Milošu, bila je i konjski smeđa vunena kapa.

Načinom odijevanja župnik se očevidno stopio sa seljačkom hrvatskom sredinom, ali se s druge strane diferencirao od Bezaka-Žminjaca na način da je nosio odjeću karakterističnu za prijašnju župu Svetog Lovreča koju je nastanjivalo vlaško stanovništvo. Možda smijemo pretpostaviti da je opisana razlika tradicionalnoga vlaškog odijevanja župnika u odnosu na bezačku sredinu njegova djelovanja dodatno bola oči Žminjcima, no raščlanjeno vrelo o tome nam izravno ne kazuje. ${ }^{145}$

Kada je u pitanju moralni život župljana, kamerlengo primjećuje visok stupanj neznanja nadodajući tome objašnjenje kako seljaci pohađaju poljske crkve gdje se ne poučava svetoj vjeri, za razliku od župne crkve. ${ }^{146}$

\footnotetext{
${ }^{143}$ Io lo ho veduto moltissime volte comprarire nella Piazza e sotto la Logia publica senza Cotta con bereta di lana color di cavallo senza abito da ecclesiastico, in camissia, e sotto calze bianche, ed alle volte in abito color di verde trattenendosi sotto la Loggia giocando alle Carte con secolari, ed alla Mora nella Bottegha con ammirazione del Popolo. BAP-BV, Knjiga 27 (1745), 334.

${ }^{144}$ Gaudemet, Storia del diritto canonico, 721-722.

${ }^{145} \mathrm{O}$ muškoj tradicijskoj odjeći u Istri vidi, npr.: Roberto Starec, Coprire per mostrare. L’abigliamento nella tradizione istriana (XVII-XIX secolo) (Trieste: Edizioni Italo Svevo, 2002). O subetnijama Vahi i Bezaki te o njihovim nošnjama vidi: Sandi Blagonić, Od Vlaha do Hrvata: austrijsko-mletačka politička dihotomija i etnodiferencijski procesi u Istri (Zagreb: Jesenki i Turk, 2013), 32-37. i passim; Olga Orlić, "Muška tradicijska odjeća Istre u procesu konstruiranja suvremenih istarskih identiteta" (magistarski rad, Sveučilište u Zagrebu, 2008), 29-30, 77, 131, 162 i passim.
}

${ }^{146}$ BAP-BV, Knjiga 27 (1745), 334. 
Politički senzibilitet laičkih predstavnika kòmuna dolazi do izražaja kroz svjedočanstvo aktualnoga župana o župniku i ostalim svećenicima prema kojima, u kontrapunktu prvotnoga sipanja salvi pohvala, kazuje: Bilo bi dobro da mons. biskup ozbiljno upozori ove svećenike da se ne upliću u sekularna pitanja i njihove interese (...), kao što je izbor sudaca i župana ${ }^{147}$ što se u Žminju vršio na svetkovinu sv. Jurja. ${ }^{148}$

Nekadašnji župan Jakov bio je ispitan usprkos svome nepoznavanju talijanskoga jezika (non sapendo di parlare in Italiano). Kako smo na početku ovoga članka napomenuli, u biskupovoj pratnji bio je i don Antonio Ravasini, župnik Novaka. Taj visitator di Campagna imao je ulogu prevoditelja za hrvatsko stanovništvo u čemu se istaknuo upravo u Žminju prve polovice srpnja 1745. godine. Jakov će usrdno moliti biskupa da dopusti seljacima imati misu u poljskim crkvama i za blagdana (ne giorni di Festa) jer ju tada nisu imali. ${ }^{149}$ Monsinjor Negri zaključno će na ovo traženje nekadašnjega župana dopustiti seljacima koji žive u okolici crkve Sv. Kvirina, kojih je oko dvjesto duša, da izaberu svećenika kojega će on potvrditi. Ovaj ima služiti u toj crkvi, to jest misiti blagdanima (Celebrare la santa messa le feste) i poučavati vjeronauk, a prema izraženoj želji stanovnika ovoga područja, sami će ga plaćati. Biskup napominje da se najvažniji blagdani nisu smjeli slaviti u toj crkvi ${ }^{150}$ jer se očekivao pohod u kolegijalnu i župnu crkvu svih župljana.

Monsinjor Negri upitao je župnika i suca Žufića o javnim grješnicima, a prema odgovorima ispada da u župi nije bilo takvih krimena. U narodu - prema župnikovu saznanju - nema ni zavada, a o javnim grješnicima, iako je upitan, nije zabilježen odgovor ili ovaj nije izrekao ni riječi ${ }^{151}$ Odnos prema javnim grješnicima, istaknuo je, onakav je kako bi se moglo i očekivati u ancien regimeu, ali tek nakon što je izrijekom o tome pitan, sudac Rovis tvrdi: Javne grješnike sekularna pravda nastoji privesti na pravi put kroz prijetnje i kažnjavanja. ${ }^{152} \mathrm{O}$ ovome problemu nešto konkretnije saznajemo tridesetak godina ranije (1710. godine) kada će župnik Rovis (zacijelo sa zadovoljstvom) istaknuti kako u njegovoj pastvi nema izopćenika, preljubnika, zelenaša i čarobnjaka iz čega proizlazi da u Žminju osvitom 18. stoljeća nema javnih grješnika. ${ }^{153}$ Ipak, ispitivani predstavnik civilnih vlasti tom je prilikom spomenuo postojanje jedne žene za koju ne zna odakle je došla, ali se

\footnotetext{
${ }^{147}$ BAP-BV, Knjiga 27 (1745), 337.

${ }^{148}$ Bratulić, "Urbari pazinskog feuda”, 180.

${ }^{149}$ BAP-BV, Knjiga 27 (1745), 339.

${ }^{150}$ BAP-BV, Knjiga 27 (1745), 65-66.

${ }^{151}$ BAP-BV, Knjiga 27 (1745), 308.

${ }^{152}$ Vi sono de Peccatori publici e questa Giustizia Secolare procura di ridurli a' dovere colle minazie e con li casighi. BAP-BV, Knjiga 27 (1745), 341.

${ }^{153}$ BAP-BV, Knjiga 17 (1710), 102.
} 
za nju govori da je na lošemu glasu (di mal sorte) te ju je dao uhititi pa se nalazi u pazinskome zatvoru. ${ }^{154}$

Upravitelji crkava, pojedinih oltara i bratovština u vrijeme biskupa Negrija i župnika Miloša bili su mahom svjetovnjaci kako je i vidljivo iz priloženog popisa (Vidi Tablica 5). Broj bartovštinskih udruženja sveo se godine 1745. najmanje na njih jedanaest $s$ time da su čak tri združene pod jednim upraviteljem, to jest gastaldom Martinom Tankovićem. Prema popisu gastalda i upravitelja crkava i pojedinih oltara omogućeno nam je zamijetiti odražavanje etnički heterogene slike onodobne pastve u kojoj hrvatske prezimenske tvorbe bjelodano prevladavaju.

Tablica 5. Upravitelji crkava i oltara u Žminju 1745. godine $e^{155}$

\begin{tabular}{|l|l|}
\hline Naziv instituta & Ime i prezime upravitelja \\
\hline Presveti Sakrament & Sante Kablar (Sante Cablar) \\
\hline Sv. Mihovil & Martin Tanković (Martino Tancovich) \\
\hline Presveti ružarij & Ivan Vadanjel (Giovanni Vadagnel) \\
\hline Čistilište & Don Franjo Rovis (Don. Francesco Rovis) \\
\hline Sv. Petar & Mihovil Krševan (Michiel Chersevan) \\
\hline Sv. Križ & župnik Miloš (Piovano provisorio modo) \\
\hline Sv. German & Mihovil Debeljuh (Michiel Debeliuch) \\
\hline $\begin{array}{l}\text { Sveta Marija Svetomore (Madona sotto } \\
\text { More) }\end{array}$ & Martin Ferlin (Martino Ferlin) \\
\hline Sv. Ivan & Antun Roža (Antonio Rosa) \\
\hline Sv. Matej u Ceru (in Cerre) & Grgo Benčić (Gergo Bencich) \\
\hline Sv. Juraj & Frane Peteh (Frane Petech) \\
\hline Sv. Margarita i sv. Elena & Ivan Zaharija (Giovanni Zaccaria) \\
\hline Sv. Augustin & Ive Pifar (Jue Piffar) \\
\hline Sv. Kirin & Matija Debeljuh (Mattio Debeluch) \\
\hline Sv. Bartul & Ive Jurkota (Jue Jurcotta) \\
\hline Presveto Trojstvo & Ivan Filipić (Giovanni Fillipich) \\
\hline Sv. Antun Opat & sudac Ivan Črnja (Giudice Giovanni Cergna) \\
\hline Sv. Foška & sudac Petar Ravnić (Giudice Pietro Ravnich) \\
\hline La Madona sotto Loco & Jakov Peteh (Giacomo Petech) \\
\hline Sv. Jakov & Martin Peteh (Martino Petech) \\
\hline & \\
\hline
\end{tabular}

$\overline{{ }^{154} \text { BAP-BV, Knjiga } 17}$ (1710), 100.

${ }^{155}$ BAP-BV, Knjiga 27 (1745), 94. 
Tablica 6. Bratovštine i njihovi upravitelji u Žminju 1745. godine gr6 $^{156}$

\begin{tabular}{|l|l|}
\hline Naziv bratovštine & Ime i prezime gastalda \\
\hline Svi Sveti & Marin Ravnić (Marin Ravnich) \\
\hline Sv. Barbara & Nikola Črnja (Nicolo Cergna) \\
\hline Bl. Djevica Marija od Karmela & $\begin{array}{l}\text { sudac Marin Krvanica (Giudice Marino } \\
\text { Chervanizza) }\end{array}$ \\
\hline Sv. Josip (bratovština i juspatronat) & nasljednici Marinčić (eredi Marincich) \\
\hline $\begin{array}{l}\text { Sv. Antun Padovanski (bratovština i } \\
\text { juspatronat) }\end{array}$ & nasljednici Bianchi (Eredi Bianchi) \\
\hline Sv. Sebastijan & Martin Tanković (Martino Tancovich) \\
\hline Sv. Mihovil & Martin Tanković (Martino Tancovich) \\
\hline Sv. Katarina & Martin Tanković (Martino Tancovich) \\
\hline
\end{tabular}

\section{Sažimanje uvida}

Vizitacijski zapisnici kao temelj naših spoznaja o vjerskoj praksi i društvenoj zbilji predstavljaju tek dio zabilježene memorije, počesto dajući naglasak i posljedično tomu opsežniji prostor neugodnim datostima, dakle sukobima i poteškoćama ili pak neurednostima koje valja smiriti, riješiti i ispraviti, što je i cilj svakoga vizitacijskog ophoda. Zato nam ostaju pomalo u sjeni prikrivene pozitivne pojave vjerskoga djelovanja koje treba razotkriti pomnjivijim iščitavanjima redaka ovakvih zapisnika.

Župa Žminj, kako bilježi historiografija, sredinom 18. stoljeća sastavnicom je Porečke biskupije te u državnome smislu pripada Svetome Rimskom Carstvu. Žminjština toga vremena predstavlja dominantnu, prezimenski promatrano, hrvatsku sredinu, dok su ostale osobe talijanskih prezimenskih oblika. Takvo stanje zorno dokazuje u ovome članku prikazan sastav njezinih gastalda bratovština kao i upravitelja crkava i oltara. Opisano narodnosno ozračje pojačavaju i većinski zastupljeni prezimenski oblici u korpusu žminjskoga klera kao i tradicijska nošnja župnika. Suživot spomenutih dvaju kulturnih krugova ocijenili bismo neupitnim i mirnim, dok su zabilježene trzavice među pojedincima odraz neusklađenih osobnosti.

Uz župnika koji je bio ujedno i kanonik, u Žminju je boravio još jedan kanonik čija je služba bila sudjelovanje u koru te misiti u kolegijalnoj crkvi. Tu je i kapelan kurat kojega je kao trećega nadarbenika župe trebao birati kaptol, a potvrđivao ga je porečki biskup. I on je - poput župnika i kanonika - imao služiti u kolegijalnoj crkvi Sv. Mihovila. Ostali svećenici svoju dužnost slavljenja mise obavljali

\footnotetext{
${ }^{156}$ BAP-BV, Knjiga 27 (1745), 95. Bratovština je u Žminju 1745. godine bilo - slijedeći zapise u vizitatio rerum - jedanaest, a ovaj očevidno nepotpuni zapis nudi popis od njih osam s navedenim imenima gastalda. Orbanić; Uljančić Vekić, "Prilog proučavanju”, 47.
} 
su na pojedinim oltarima i područnim crkvama ovisno gdje su bili izabrani i tko ih je birao. Župa Žminj je uz brojne duhovnike tada imala zvonara, sakristana i svećenika orguljaša.

Hodočašća i procesije obavljale su se neovisno o tadašnjim državnim i biskupijskim granicama, što sve prepoznajemo kao odraz bujajućega europskog katoličanstva prve polovice 18. stoljeća. Žminjci su tako pješačili u pavlinski samostan u Svetome Petru u Šumi, u pićansku katedralu i u obližnji Svetvinčenat častiti zemne ostatke sv. Viktorije te u Rovinj sv. Eufemiji u pohode. Tijekom takozvanih duhovno jakih vremena imali su prigodu svakodnevno slušati vrsne propovjednike koji bi bili pozivani i izvan Istre.

Nadalje, župljani su se promatrane 1745. godine okupljali u jedanaest crkvenolaičkih udruženja, to jest bratovština od kojih su neke, poput primjera Bratovštine Duša u Čistilištu, u sporu sa župnikom rješenje potražile kod svjetovne pravde.

Ni na jednome mjestu raščlanjenih vrela nije zabilježena bojazan od gladi i siromaštva, što može upućivati na neku vrstu stabilne žminjske konjunkture zacijelo bazirane najvećim dijelom na poljoprivredi i stočarstvu. Ujedno, ratnih strahota na ovim prostorima nije bilo od Uskočkih ratova prve polovice 17. stoljeća. Posljedično opisanomu, kakvo-takvo blagostanje i mir plodan su okvir i za dogradnju sakralnih zdanja, što je bjelodano i učinjeno pothvatima na žminjskoj župnoj crkvi i crkvi Sv. Foške u prvoj polovici 18. stoljeća. 


\section{Izvori}

Republika Slovenija - Arhiv Republike Slovenije - Reprezentanca in komora za Kranjsko.

Republika Hrvatska - Biskupijski arhiv u Poreču - Biskupske vizitacije, Knjiga osme vizitacije Aleksandra Adelsija, Adelasio Octavae visitationis generalis, 2.17 (1710).

Biskupijski arhiv u Poreču - Biskupske vizitacije - Generalna vizitacija biskupa Negrija u austrijskom dijelu biskupije, Negri Visitatio Generalis a Parte Austriaca, 2.27 (1745).

Republika Hrvatska - Državni arhiv u Pazinu - Zbirka matičnih knjiga, Matična knjiga krštenih Pazin (1655.-1689.) HR-DAPA-429.

Republika Hrvatska - Državni arhiv u Pazinu - Zbirka matičnih knjiga, Matična knjiga umrlih Žminj (1716.-1774.) HR-DAPA-429.

Republika Hrvatska - Državni arhiv u Pazinu - Zbirka preslika gradiva iz arhiva i ustanova RH, DVD 5, ZM34K-135, Matična knjiga umrlih Žminj (1775.-1812.) HR-DAPA-861

Republika Hrvatska - Župni ured Žminj, Matična knjiga krštenih Žminj (1662.1713.).

Republika Hrvatska - Župni ured Žminj, Matična knjiga krštenih (1716.-1746.).

Republika Hrvatska - Župni ured Žminj, Matična knjiga umrlih (1784.-1812.).

Republika Hrvatska - Župni ured Žminj, Knjiga bratovštine Presvetog Sakramenta. 18. stoljeće.

\section{Objavljeni izvori i literatura}

Alberi, Dario. Istria: storia, arte, cultura. Trieste: Lint, 1998.

Babudri, Francesco. "I vescovi di Parenzo e la loro cronologia", Atti e Memorie della Societa Istriana di Archeologia e Storia Patria 25 (1909): 170-278.

Battisti, Carlo; Alessio, Giovanni."Camerlengo". U: Dizionario etimologico italiano, vol. 1, 697. Firezna: Barbèra, 1975.

Benussi, Bernardo. Storia documentata di Rovigno. Trieste: Unione degli Italiani dell'Istria e di Fiume; Universita popolare di Trieste, 1977.

Bérenger, Jean. "The Austrian Church". U: Church and society in Catholic Europe of the eighteenth century, uredili William J. Callahan, David Higgs, 88-105. Cambridge; New York: Cambridge University Press, 2008.

Bertoša, Miroslav. Etos i etnos zavičaja. Pula; Rijeka; Rovinj: Čakavski sabor; Istarska naklada; Otokar Keršovani; Centro di ricerche storiche, 1985. 
Bertoša, Miroslav. "Istra se zove različitost. Kolonizacijski etnički iceberg XVI.XVIII. stoljeća”. Istra (1987), br. 5-6: 167-173.

Bertoša, Slaven. “Rampel (Rampelli)”. U: Istarska enciklopedija, 673. Zagreb: Leksikografski zavod Miroslav Krleža, 2005.

Bertoša, Slaven. "Brigido, feudalna plamićka obitelj”. U: Istarska enciklopedija, 100-101. Zagreb: Leksikografski zavod Miroslav Krleža, 2005.

Blagonić, Sandi. Od Vlaha do Hrvata: austrijsko-mletačka politička dihotomija $i$ etnodiferencijski procesi u Istri. Zagreb: Jesenki i Turk, 2013.

Boerio, Giuseppe. Dizionario del dialetto veneziano, Ristampa anastatic. Milano: Aldo Martello editore, 1971.

Bolonić, Mihovil. "Seoski kaptoli u Krčkoj biskupiji”, Bogoslovska smotra 36 (1966): 122-145.

Bratulić, Vjekoslav. "Urbari Pazinskog feuda (XVI stoljeća)”, Vjesnik historijskih arhiva u Rijeci i Pazinu 8-9 (1963 - 1964): 139-204.

Bratulić, Josip. “Žminj u Istarskom razvodu”. U: Libri žminjski, sv. 2., urednik Slavko Krajcar, 55-63. Žminj: Katedra Čakavskog sabora Žminj, 2008.

Carić, Ante. Mlađe osobe u kaznenom pravu (počinitelji $i$ žrtve). Zagreb: Pravni fakultet, 2002.

“Cattedratico". U: Lexicon latinitatis medii aevi Iugoslaviae, sv. 1, 194. Zagreb: Editio Instituti historici Academiae scientiarum et artium Slavorum meridionalium, 1973.

Cvitanović, Đurđica. “Srce Zagorja u srcu Istre”. U: Sv. Petar u Šumi nekad i danas, uredili Mario Bratulić i Ladislav Turčinović, 33-51. Sv. Petar u Šumi: MZ Sv. Petar u Šumi, 1989.

Juričić-Čargo, Danijela. "Arhivska građa za povijest Pazina i Pazinske grofovije u upravnim fondovima Arhiva Republike Slovenije", Vjesnik istarskog arhiva 2-3 (1992 - 1993): 213-251.

De Franceschi, Camillo. Storia documentata della Contea di Pisino. Venezia: editrice Societa' Istriana di Archeologia e Storia Patria, 1964.

De Totto, Gregorio. "Feudi e feudatari nell'Istria veneta”. Atti e Memorie della Societa Istriana di Archeologia e Storia Patria 51-52 (1939 - 1940.): 51-107.

Di Paoli Paulovich, David. Cosi' Rovigno canta e prega a Dio. Rovigno: Centro di richerche storiche; Unione Italiana; Universita popolare, 2011.

Fučić, Branko. Glagoljski natpisi. Zagreb: Jugoslavenska akademija znanosti i umjetnosti, 1982.

Gaudemet, Jean. Storia del diritto canonico. Milano: Edizioni San Paolo, 1998.

Grah, Ivan. "Pazinski kraj u izvještajima pićanskih i porečkih biskupa Svetoj Stolici (1588-1780)”, Vjesnik historijskih arhiva u Rijeci i Pazinu 26 (1983): 201-218. 
Grah, Ivan. "Izvještaji porečkih biskupa Svetoj Stolici (1588-1775)", Croatica Christiana periodica 7 (1983) br. 12: 1-47.

Grah, Ivan. "Sjemeništa i teološko obrazovanje na području istarskih biskupija". U: Visoko školstvo na području Riječko-senjske metropolije, uredio Mile Bogović, 221-244. Zagreb; Rijeka: Kršćanska sadašnjost; Teologija u Rijeci, 1999.

Herkov, Zlatko. "Beneficium”. U: Financijsko-pravni rječnik feudalne epohe Hrvatske, sv. 1, 103. Zagreb: Jugoslavenska akademija znanosti i umjetnosti, 1956.

Ivetic, Egidio. "La popolazione di Parenzo del Settecento: aspetti, prolemi ed episodi del movimento demografico", Atti CRSR 21 (1991), 117-185.

Ivetic, Egidio. La popolazione dell'Istria nell'eta' moderna. Lineamenti evolutivi. Trieste; Rovigno: Unione italiana - Fiume; Univerista’ popolare di Trieste, 1997.

Jelinčić, Jakov. "Novigradska kancelarija (Istarski Novigrad) u XVIII. st. do pada Venecije (1797.)". Magistarski rad, Sveučilište u Zadru, 1976.

Jelinčić, Jakov; Uljančić Vekić, Elena. "Popis lokaliteta pastoralnih vizitacija porečkih biskupa u 17.i 18. st., Vjesnik istarskog arhiva 8-10 (2001 - 2003): 107-174.

Jelinčić, Jakov. “Vizitacija porečkog biskupa Gaspara Negrija iz 1743.-1748.” U: 2. Istarski povijesni biennale, uredio Neven Budak, 191-217. Poreč: Zavičajni muzej Poreštine; Sveučilište Jurja Dobrile u Puli; Državni arhiv u Pazinu, 2007.

Jelinčić, Jakov. Knjiga ređenja u Pićnu (Prothocollum) 1632.-1783. Pazin: Državni arhiv u Pazinu, 2015.

Juričić-Čargo, Danijela. "Arhivska građa za povijest Pazina i Pazinske grofovije u upravnim fondovima Arhiva Republike Slovenije" Vjesnik istarskog arhiva 2-3 (1992 - 1993): 213-251.

Križman, Mate. "Isprava pape Aleksandra III. iz 1178. godine. Paleografski i filološki pristup”. U: Libri žminjski, sv. 2, urednik Slavko Krajcar, 27-39. Žminj: Katedra Čakavskog sabora Žminj, 2008.

Marković, Vladimir. Crkve 17. i 8. st. u Istri: tipologija i stil. Zagreb: Institut za povijest umjetnosti, 2004.

Milovan, Ivan. Savičenta: jučer, danas. Umag: Tipografija Umag, 1975.

Molinier, Alain. "Parroci e parrocchiani della Controriforma". U: Storia vissuta del popolo cristiano, uredio Jean Delumeau, 587-613. Torino: Società editrice internazionale, 1985.

Neralić, Jadranka. Put do crkvene nadarbine. Split: Književni krug, 2007.

Nežić, Dragutin. “Čestohovska Gospa u Sv. Petru u Šumi. Godine 1721. prosuzila njezina slika” Ladonja (Pazin), lipanj 1987., 8-9.

Orbanić, Elvis; Uljančić Vekić, Elena. "Prilog proučavanju crkvene i društvene povijesti Žminjštine u prvoj polovici 18. stoljeća”. U: Libri žminjski, sv. 1, uredio Slavko Krajcar, 39-63. Žminj: Katedra Čakavskog sabora Žminj, 2008. 
Orbanić, Elvis. “Društveni i religiozni život Porečke biskupije „a parte Imperij“ u 17. st.: primjer Pazina, Starog Pazina, Svetog Petra u Šumi i Žminja”. Doktorska disertacija, Sveučilište u Zagrebu, 2012.

Orbanić, Elvis (priredio). Ignazio Gaetano de Buset: visita spirituale del 1788 in Istria /Ignacije Kajetan Buzetski: duhovna vizitacija iz 1788 u Istri, Citta' del Vaticano: Associazione archivistica ecclesiastica, 2016.

Orbanić, Elvis; Peteh, Nela. "Žminjske kapelice: povijest jedne pučke pobožne prakse”. Riječki teološki časopis 24 (2016), br. 1: 67-98.

Orlić, Olga. "Muška tradicijska odjeća Istre u procesu konstruiranja suvremenih istarskih identiteta". Magistarski rad, Sveučilište u Zagrebu, 2008.

Pavat, Mario. La riforma tridentina del clero a Parenzo e Pola. Roma: ex Pontifica Universitate Gregoriana, 1960.

"Pazinska knežija". U: Hrvatska enciklopedija, svezak 8, 345. Zagreb: Leksikografski zavod Miroslav Krleža, 2006.

Petronio, Prospero. Memorie sacre e profane dell'Istria. Trieste: Tip. G. Coana, 1968.

Radisavljević, Slobodan. "Musketa". U: Vojna enciklopedija, svezak 5, 660-661. Beograd: izdanje Redakcije Vojne enciklopedije, 1973.

Radole, Giuseppe. "Gli organi nelle chiese istriane", Atti e Memorie della Societa Istriana di Archeologia e Storia Patria 16 (1968), LXVIII della Racolta: 127-142.

Rendić-Miočević, Ivo. Hrvatski identitet: trajnost i fluidnost. Usporedba Kvarnera i gorske Dalmacije. Rijeka: Adamić, 2006.

Santa Vittoria, pristup ostvaren 30. 5. 2016., http://www.santiebeati.it/dettaglio/90643

Starec, Roberto. Coprire per mostrare. L'abigliamento nella tradizione istriana (XVII-XIX secolo). Trieste: Edizioni Italo Svevo, 2002.

Sušić, Zvonimir. "Valvasor o Istranima. Preveo s njemačkog originala i bilješke napisao dr. Zvonimir Sušić, Dometi 5 (svibanj 1970): 87-99.

Šimunović, Petar. Hrvatska u prezimenima. Zagreb: Golden marketing; Tehnička knjiga, 2008.

Šonje, Ante. Žminj i Žminjština. Žminj: Katedra čakavskog sabora Žminj, 1976.

Štoković, Alojz. “Žminjske bratovštine”. U: Libri žminjski, sv. 2, uredio Slavko Krajcar, 83-91. Žminj: Katedra Čakavskog sabora Žminj, 2008.

Uljančić Vekić, Elena. “Župnici, župani i suci u zapisnicima pastoralnih vizitacija 17. i 18. stoljeća: primjer Žbandaja i Vabrige”. Acta Histriae 17 (2009): 251-276. 


\title{
Religious and Social Climate in Žminjština during the First Half of the 18th Century
}

\author{
Elvis Orbanić \\ State Archives in Pazin \\ Vladimira Nazora 3 \\ 52000 Pazin \\ Croatia \\ E-mail: elvis.orbanic@dapa.hr
}

\section{Summary}

Visitation records as the basis of our knowledge on the religious practice and social reality are only a part of the documented memory, often accentuating and thus privileging its unpleasant aspects: conflicts, difficulties, and disorderly circumstances that had to be appeased, solved, and corrected, which was the aim of all visitations. For this reason, the positive aspects of such religious activities often remain hidden and must be disclosed by carefully reading through the lines of these records.

The parish of Žminj, as one reads in historiography, was under the jurisdiction of the Poreč (Parenzo) bishopric during the 18th century, and thus officially part of the Holy Roman Empire. At that time, Žminjština was a predominantly Croatian area, judging from the family names, and the rest of its population was Italian. This situation is reflected in the family names of confraternity gastalds, analysed in this article, as well as those of administrators of churches and altars. This ethnic composition is also evident in most family names of Žminj's clergy and the parish priest (despite the inadequacy), which is why the analysed document also notes the traditional folk costume that he wore. The cohabitation of these two cultural circles was unchallenged and peaceful, in our opinion, and the recorded conflicts among individuals simply reflect personal incompatibilities.

Besides the parish priest, who was also a canon, there was another canon in Žminj, whose duty was to take part in the choir and to celebrate the Mass at the collegiate church. There was also a chaplain curate, who was appointed by the chapter as the third prebendary of the parish and confirmed by the bishop of Poreč. Same as the parish priest and the other canon, he was to serve at the collegiate church of St Michael. Other priests celebrated the Mass at specific altars and subsidiary churches, depending on where they were appointed and by whom. Besides a number of priests, the parish of Žminj had a bell ringer, a sacristan, and an ordained organist. 
Pilgrimages and processions took place regardless of the state and diocesan borders, which one may consider as a sign of the flourishing European Catholicism during the first half of the 18th century. The Žminjans used to walk to the Pauline monastery of Sv Petar u šumi (San Pietro in selve), the cathedral of Pićan, to the nearby Svetvinčenat to venerate the relics of St Victoria, and to Rovinj to pay respects to St Euphemia. During the spiritually turbulent times, they had the opportunity to listen to excellent sermons on a daily basis, held by preachers who were also invited to places outside Istria.

Moreover, during the year on which this research focuses, the parishioners of Žminj were members of eleven different ecclesiastical-lay associations - confraternities, some of which, such as the Confraternity of Souls in Purgatory, even appealed to the secular authorities to settle their conflict with the parish priest.

None of the analysed sources mentions fear of famine or poverty, which may indicate a sort of stable infrastructure, probably largely based on agriculture and cattle breeding. Wartime destruction had not been known since the Uskok Wars in the first half of the 17th century. This state of peace and relative welfare made it possible to enlarge sacral buildings during the first half of the 18th century, such as the parish church of Žminj or the church of St Fosca.

Keywords: Žminj, Poreč bishopric, religious life, demography, visitations 